\title{
Risk factors for dental caries in Latin American and Caribbean countries
}

\section{Stefania MARTIGNON(a) \\ Angelo Giuseppe RONCALLI(b) (iD) \\ Evelyn ALVAREZ(c) \\ Vicente ARÁNGUIZ(d) \\ Carlos Alberto FELDENS(e) iD \\ Marília Afonso Rabelo \\ BUZALAF(f) (iD)}

(a) Universidad El Bosque, Caries Research Unit, Research Department, Bogotá, Colombia.

(b) Universidade Federal do Rio Grande do Norte - UFRN, Department of Dentistry, Natal, RN, Brazil.

(c) Universidad Científica del Sur, School of Dentistry, Department of Pediatric Dentistry, Lima, Perú.

(d) Universidad de los Andes, Faculty of Dentistry, Cariology Unit, Santiago, Chile.

(e) Universidade Luterana do Brasil, School of Dentistry, Department of Pediatric Dentistry, Canoas, RS, Brazil.

(f) Universidade de São Paulo - USP, Bauru School of Dentistry, Department of Biological Sciences, Bauru, SP, Brazil.

Declaration of Interests: The authors certify that they have no commercial or associative interest that represents a conflict of interest in connection with the manuscript.

Corresponding Author:

Stefania Martignon

E-mail: martignonstefania@unbosque.edu.co

ht1ps://doi.org/10.1590/1807-3107bor-2021.vol35.0053

Submitted: March 9, 2021

Accepted for publication: March 9, 2021

Last revision: March 15, 2021
Abstract: Identifying the risk factors for dental caries is vital in epidemiology and clinical practices for developing effective preventive strategies, both, at the individual and collective levels. Different causality/determination models have been proposed to understand the development process of dental caries. In the present review, we designed a model inspired by the world-known social determinants models proposed in the $90 \mathrm{~s}$ and more recently in the 10s, wherein the contextual factors are placed more externally and encompass the individual factors. The contextual factors included those related to the cultural and societal values, as well as the social and health government policies. The individual factors were classified into the following categories: socioeconomic (social class, occupation, income, and education level), demographic characteristics (age, sex, and ethnicity), behavioral factors (non-use of fluoride dentifrice, sugar consumption, poor oral hygiene, and lack of preventive dental care), and biological factors (recent caries experience/active caries lesions, biofilm retentive factors, developmental defects of the enamel, disabilities, saliva amount and quality, cariogenic biofilm). Each of these variables was addressed, while focusing on the current evidence from studies conducted in Latin American and Caribbean countries (LACC). Based on the proposed model, educational aspects were addressed, and individual caries risk assessment and management decisions were proposed; further, implications for public health policies and clinical practice were described. The identification of modifiable risk factors for dental caries should be the basis for multi-strategy actions that consider the diversity of Latin American communities.

Keywords: Dental Caries; Risk Factors; Socioeconomic Factors; Health Risk Behaviors; Biology

\section{Introduction}

A caries risk factor is defined as a factor/determinant, confirmed by temporal sequence and directly associated with an increased probability of caries. ${ }^{1}$ The identification of caries risk factors is important in epidemiology and clinical practice for the development of effective preventive strategies at both, the individual and collective levels.

The theoretical assumption of causality and determination is hereby exposed in a model that describes how risk factors interact to pose a greater 
risk for the occurrence of dental caries. Although most factors are well documented in the literature, only description and knowledge of their respective mechanisms of action is insufficient. It is important to discuss the complex interplay among these factors.

Different causality/determination models have been proposed to understand the developmental process of caries. Many of these arise from the authors' theoretical elaborations, scientific literature,,$^{2-5}$ or statistical and mathematical processes; with the latter, as recently proposed by Foley and Akers ${ }^{6}$ who used the causal model based on the Directed Acyclic Graphs that maps the association between variables, creating a causal network. Other models are based on the existing proposals, such as the well-known social determinants model by Dahlgren and Whitehead ${ }^{7}$ that employs concentric circles from the most proximal to the most distal factors. Several authors have adapted this model for oral health outcomes ${ }^{8-11}$ by changing some variables while maintaining the idea of concentric circles.

In our study, we employed a modified model inspired by different approaches. One approach was the proposal developed by the World Health Organization $(\mathrm{WHO})^{12}$ to guide actions focused on the social determinants of health. The social determinants model $^{7}$ was also incorporated, recognizing the presence of distal and proximal factors in the determination of dental caries. In this model, the contextual factors are placed more externally, although they encompass the individual factors, not constituting themselves in different dimensions or belonging to the same level of determination. The contextual factors include those related to the cultural and societal values, as well as the social and health policies of the government. The individual factors were classified into the following categories: socioeconomic, demographic, behavioral, and biological factors (Figure 1). Each of these groups was composed of different variables that are discussed later in this article.

Considering the relevance of the consensus papers on caries that was very inclusive within the LACC, we developed the present critical narrative review. An electronic search of the dental literature was conducted in the PubMed, Scopus, LILACS, and SciELO databases, with appropriate keywords and/or phrases; further, a manual search was conducted.

\section{Contextual factors}

\section{How are contextual factors usually assessed?}

The assessment of the contextual effect on health outcomes is generally performed based on ecological studies, wherein a correlation between the aggregated values at different population levels (cities, states, and countries, in most cases) is analyzed. Since the mid-90s, multilevel models have been used frequently. A limitation of these studies, particularly in the area of oral health, is the poor quality or lack of data on the main problems in oral health, such as dental caries, that are discussed in greater detail in papers 1 and 5 of this LAOHA caries consensus. ${ }^{13,14}$ The main repository of WHO-sponsored oral health data, the Oral Health Country/Area Profile Project (see at https://capp.mau. se/) maintained by Malmö University presents data from virtually every country in the world. However, these data are quite outdated and have poor accuracy. For some LACC, the most recent information available is $>20 \mathrm{y}$ old, and very few population-based studies are representative of the entire country. However, in spite of these restrictions, the information can be used to assess the global profile of dental caries and the effect of contextual factors.

Databases are more reliable and provide more comprehensive information on socioeconomic variables. Worldwide, numerous researchers have tried to identify the relationship between health and socioeconomic indicators from these databases. In the field of oral health, most of them are based on the comparison of Decayed, Missing, and Filled Teeth (DMFT/dmft) index in different categories of socioeconomic indicators.

\section{Dental caries and contextual factors in LACC}

To understand the specificity of the relationship between dental caries and some contextual factors in the 33 countries included in the LACC, we performed an analysis with the data available from the cited sources. Data related to some socioeconomic indicators were gathered from the United Nations Development Programme (UNDP) (http://www.hdr.undp.org/en/ data) and the World Bank (https://data.worldbank. org/). Previously collected 12-year DMFT data were 


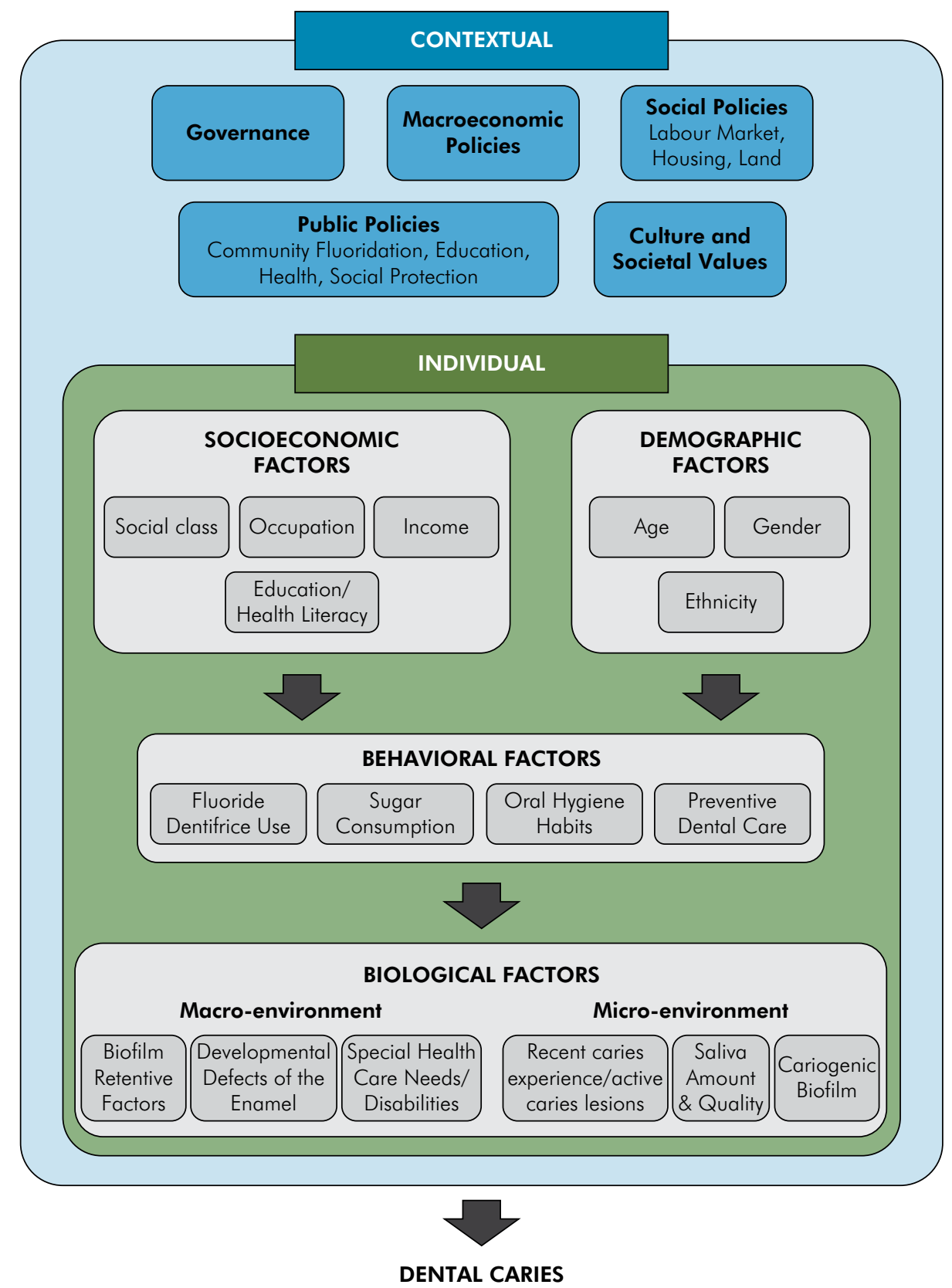

Figure 1. Conceptual framework for the caries risk factors inspired by the WHO Framework ${ }^{12}$ and by Dahlgren and Whitehead. ${ }^{7}$ Material created by the authors.

obtained from the aforementioned Oral Health Country/ Area Profile Project (https://capp.mau.se/). When possible, the database was updated based on a literature search. The reference years in the DMFT database ranged from 1995 to 2014; therefore, we used the socioeconomic data of a year as close as possible. Countries for which data were unavailable for both the variables were excluded from the analysis.
Figure 2 shows the correlation between the DMFT at the age of $12 \mathrm{y}$ and the Human Development Index (HDI), with a weak negative correlation being observed between them; however, the small number of observations rendered no statistical significance and only indicated plausibility.

A similar trend was observed with the Gini index (Figure 3), albeit with a positive relationship; higher 


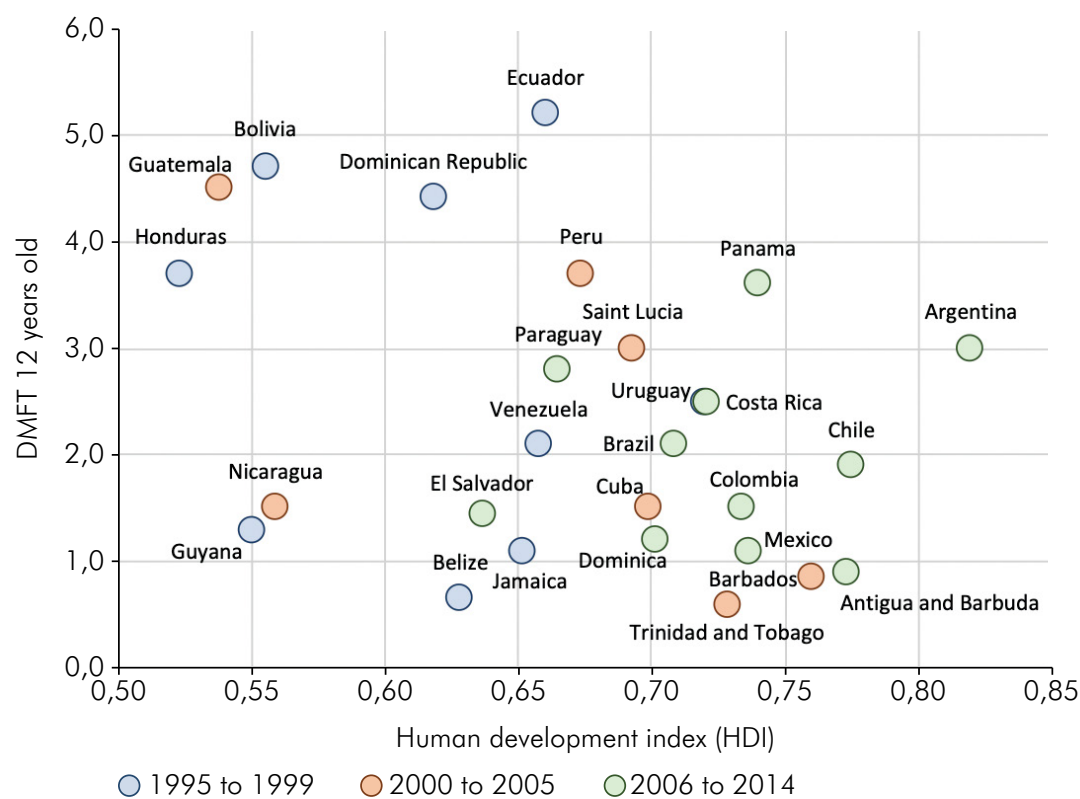

The Human Development Index (HDI) is a statistic composite index of life expectancy, education (Literacy Rate, Gross Enrollment Ratio at different levels and Net Attendance Ratio), and per capita income indicators that are used to rank countries into four tiers of human development. Countries that score higher show greater achievements; Different colors represent the range of years when the data were collected; The circle size is proportional to the population; Pearson correlation only for LACC $(r=-0.345 ; p=0.078)$; Source: Prepared by the authors from the data available at the United Nations Development Programme (UNDP) and the Oral Health Country/Area Profile Project.

Figure 2. Correlation between DMFT in 12-year-old children and the Human Development Index (HDI) in LACC. Material created by the authors.

the index, greater the degree of inequality. Countries with lower inequality, such as Uruguay, Jamaica, and Venezuela, and those with greater inequality, such as Ecuador and Guatemala, had lower and higher DMFT values, respectively. This analysis had some limitations, mainly regarding the low extent of the updated data; however, it is important to highlight that this profile was similar to other countries that used more recent information.

As discussed by Roncalli et al., ${ }^{15}$ an association of HDI with DMFT has been observed in Brazil and other countries. Studies using local data, such as the study conducted in Brazil, found a correlation between HDI and oral health outcomes. ${ }^{16-25}$ Trials performed in Colombia, Ardila and Agudelo-Suárez ${ }^{26}$ showed an association between low HDI and dental pain using a multilevel approach.

The HDI and the Gini index constitute two important aspects of contextual factors because they both represent both a positive characteristic relative to human development index (HDI) and a negative one relative to income inequality, as can be seen in the related Figures 2 and 3 description. This is particularly important because greater indicators of longevity, income, and education are not always associated with greater income distribution; thus, from the viewpoint of the social determination of the disease, these factors have quite different roles.

Bernabé and Hobdell ${ }^{27}$ analyzed data from 48 countries and showed an association between the Gini index and previously collected 5 to 6 -year $\mathrm{dmft}$ values. Only the 22 wealthiest countries were included; therefore, the Gini index presented a significant association, unlike the Gross National Income that showed no association. A significant association between HDI and Gini index was found with a reduction in the incidence of dental caries in Brazilian children when the associated social factors were analyzed. ${ }^{15}$

Another important aspect of contextual factors is the effect of public health and well-being policies. Such analyses are complex, owing to the difficulty of measuring the offered health services. Most studies have analyzed access to health services from an 


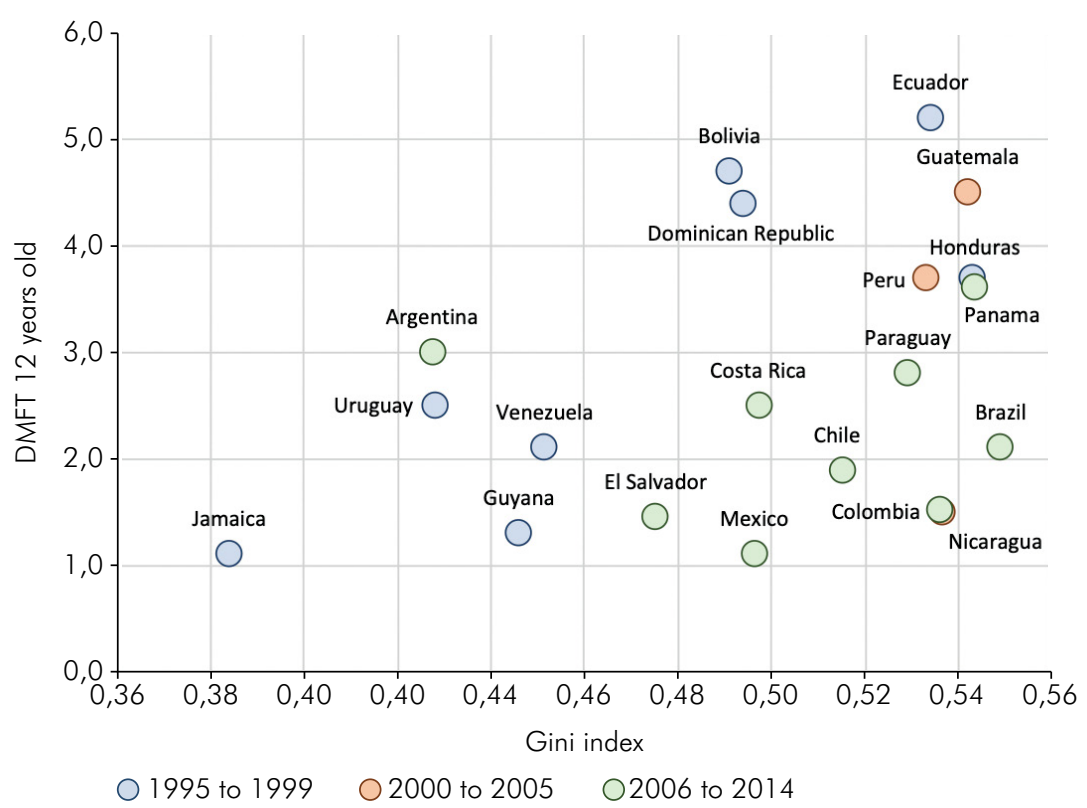

The Gini Index is a measure of statistical dispersion intended to represent the income inequality or wealth inequality within a nation or any other group of people; it measures the inequality among values of a frequency distribution (for example, levels of income). A Gini Index of zero expresses perfect equality, where all values are the same (for example, where everyone has the same income); Different colors represent the range of years when data were collected; Pearson correlation for LACC $(r=0.374 ; p=0.103)$; Source: Prepared by the authors from data available at the World Bank and the Oral Health Country/Area Profile Project.

Figure 3. Correlation between DMFT in 12 years old children and Gini Index in LACC. Material created by the authors.

individual perspective, and in general, based on the use of these services. ${ }^{22}$ Guarnizo-Herreño et al. ${ }^{28}$ reported the existence of oral health inequalities in adults in all European welfare-state regimes; further, they observed that particular behaviors played a heterogeneous role in explaining these inequalities across the evaluated welfare regimes. ${ }^{29}$

One way of assessing the effect of health policies is to estimate the extent to which countries prioritize health in their public -funding models. Relationships with the workforce, such as the inhabitant/dentist relationship or oral health services coverage is relatively common. . $19,21,30-33$ Most of these studies employ the ecological approach that has intrinsic biases that may interfere with the observation of a genuine effect. One of these biases is attributable to the exposure and outcome being observed at the same time. A given public policy takes a certain amount of time to produce measurable effects, and the best designs to assess them are longitudinal ones or those based on panel data analysis. In any case, ecological studies that aim to evaluate the correlation between the provision of health services and a specific characteristic of the health system, such as financing, are useful because they help generate hypotheses. Figure 4 shows the correlation between these variables. Countries with low investment in health, such as Bolivia, Dominican Republic, and Guatemala, have higher DMFT values. In contrast, countries, such as Argentina, Brazil, Cuba, and Uruguay, that have a higher percentage of investment, have lower DMFT values.

A relevant aspect in this context is the presence of community fluoridation programs. Among these, water fluoridation is the most commonly employed program across the world ${ }^{34}$ and is considered the most effective and socially equitable means of achieving community-wide fluoride protection against dental caries. ${ }^{35}$ The recommended fluoride water concentration ranges from 0.6 to $1.1 \mathrm{mg} / \mathrm{L}^{36}$ depending on the climate, to achieve a balance between the potential for dental caries reduction and development of dental fluorosis. ${ }^{35}$ Water fluoridation programs have an estimated cost of US\$ 0.11-4.92/year/capita, ${ }^{34}$ and these measures are backed by strong evidence that has demonstrated a 


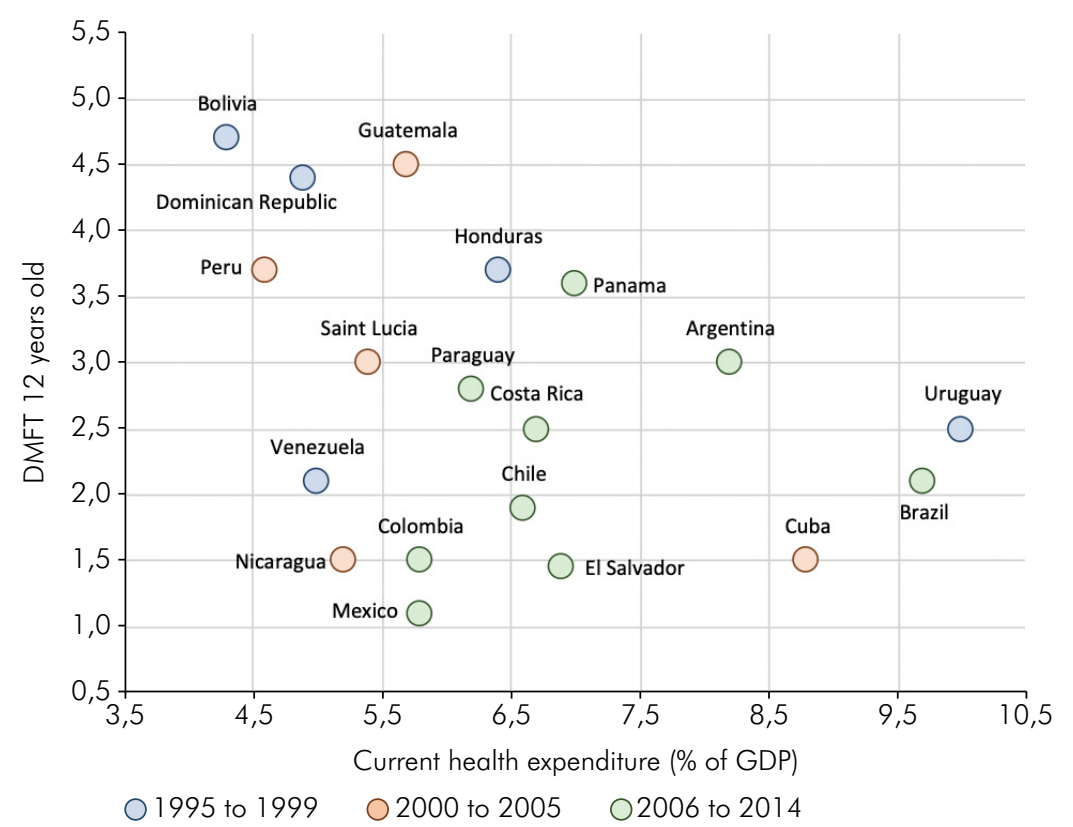

Level of current health expenditure expressed as a percentage of gross domestic product (GDP); estimates of current health; Expenditures include healthcare goods and services consumed during each year; Different colors represent the range of years when data were collected; Pearson correlation for Latin American and Caribbean countries ( $r=-0.463 ; p=0.039)$; Source: Prepared by the authors from data available at the World Bank and the Oral Health Country/Area Profile Project.

Figure 4. Correlation between DMFT in 12 years old children and current health expenditure (\% GDP) in LACC. Material created by the authors.

reduction in the caries prevalence by $26 \%-35 \% .{ }^{35-36}$ In contrast, the estimated cost of salt fluoridation is US\$ 0.02-0.05/year/capita. ${ }^{37}$ The meta-analysis by Yengopal et al. favors it but it states that related available studies are graded as poor-quality. ${ }^{38} \mathrm{~A}$ systematic review ${ }^{35}$ suggested that milk fluoridation was beneficial in preventing/reducing caries; however, the quality of evidence was also inferior to that for water fluoridation. The Pan American Health Organization (PAHO) in 1994 launched a multi-year plan to support water and salt fluoridation programs in Central America, South America, and Caribbean countries. It aimed to include more than 400 million people for both the programs by $2010 .{ }^{39} \mathrm{~A}$ table describing the type of community fluoridation and the relevant details in LACC can be found in the "Community interventions and strategies" paper of this LAOHA caries consensus document. ${ }^{40}$

The variable availability of fluoridated toothpaste across countries represents an additional contextual risk factor in Latin America, exposing a large part of the population to an increased risk of dental caries.
The legislations of most countries do not ensure that toothpastes have a minimum soluble fluoride concentration so that they exert an anti-caries effect (1,000 ppm of soluble fluoride) mostly because they prioritize the safety of fluoride toothpastes over their anti-caries potential. ${ }^{41}$

Contextual factors are not risk factors per se. They work as modulating elements that must be interpreted as the causes of the causes..$^{42}$ In other words, there is no direct way to transport the contextual effects to the individual level. This statement has important implications in the field of dental practice. While it is essential to determine the individual risk factors to guide appropriate interventions, we wish to emphasize that how individuals react to preventive and therapeutic measures depends on the context in which they live. Such reductionism enables an etiological understanding of how ecological exposures affect health; however, it may be counterproductive. In the realm of public health policy and action, contextual factors may serve as the most practical points of intervention in the chain of events. ${ }^{43,44}$ 


\section{Individual factors}

\section{Socioeconomic and demographic factors}

This group of caries risk factors comprises social class, occupation, education level, income, sex, age, and ethnicity.

Social class is defined by ownership; it explains how economic inequalities are generated, and how they can influence health..$^{45}$ There is a strong association of social and economic conditions with the occurrence of dental caries, indicating that individuals living in low socioeconomic conditions have greater exposure to risk factors that could influence their burden of dental caries ${ }^{46,47}$ A Colombian study demonstrating oral-health inequalities in early childhood found significant associations of caries experience, age, and caregivers' lower educational level. ${ }^{48}$

Occupation is an indicator of the socioeconomic position, determining the individual's place in the societal hierarchy and commonly includes parental occupation as an indicator of a child's socioeconomic position. However, the occupational indicator cannot be assigned to unemployed people; this could underestimate the socioeconomic differences. ${ }^{45}$

Education level is an indicator of the parents' socioeconomic position, determines family income, and is associated with oral health outcomes. Moreover, education provides skills and knowledge that could enable communication; therefore, people become more receptive to oral health information. ${ }^{49}$ A systematic review showed that lower parental education was associated with a higher risk of dental caries. ${ }^{50} \mathrm{In}$ a similar manner, lower maternal educational level was associated with lesser use of dental services, and these children of such mothers with scarce oral health knowledge could have poorer oral health. ${ }^{51}$ Oral health literacy has been so far considered in a systematic review as a mediator more than a direct factor for oral conditions, including dental caries. ${ }^{52}$

In addition, income is an indicator of the socioeconomic condition. Family income can be a useful indicator because family expenses are commonly shared by household members. ${ }^{45} \mathrm{~A}$ higher risk of carious lesions has been associated with lower socioeconomic level. ${ }^{46}$ In a similar manner, low -income families usually have a diet rich in sugars and fats that in turn led to a higher caries incidence in their children. Family income controls the access to education and oral health services. Therefore, low economic level is associated with scarce preventive care and lowered the prevalence of dental visits. ${ }^{46}$

Sex-based differences have been reported in epidemiological studies with a significant higher prevalence of dental caries in girls than in boys; further, more women use dental health care services. ${ }^{53,54} \mathrm{~A}$ systematic review showed a higher rate of dental caries in Brazilian women. ${ }^{51}$ Social and cultural differences between men and women could influence their oral health conditions in different manners. ${ }^{55}$

Race/ethnicity refers to social groups that share ancestry and cultural heritage. It is frequently used for identifying unequal distribution of disease burden, indicating a higher prevalence of dental caries in immigrants or ethnic minorities. ${ }^{56}$ Researchers are advised to avoid using race unless the observed differences regarding dental caries cannot be explained by genetics, and the possibility of inadvertently exhibiting racism (individual and structural) should be considered. However, race is not a proxy for racism, but an explanation that should be better studied. ${ }^{57}$ However, socioeconomic conditions play an essential role in the association between health and race/ethnicity because oral health problems particularly affect underprivileged people. ${ }^{45}$

Epidemiological surveys have demonstrated an increased prevalence of caries with age, secondary to the cumulative and chronic nature of dental caries. Considerable caries related problems can occur in adults,,$^{58}$ and older children can have more advance-staged carious lesions than younger children.

Socioeconomic and demographic factors in LACC

In a systematic review, ${ }^{51}$ a recent Brazilian population-based study showed that non-white ethnic groups had a higher prevalence of caries in children. ${ }^{26}$ Several studies conducted in Latin American indigenous people have shown a rise in the caries prevalence and severity, ${ }^{45}$ with a systematic review concluding that sex-based differences and increasing age were associated with a higher caries experience in Guarani and Xavanti groups in Brazil..$^{59}$ With respect to the parents' low educational level, an association was 
found with higher caries prevalence in cross-sectional studies conducted in Colombia, ${ }^{60}$ Mexico, ${ }^{61}$ and Chile. ${ }^{62}$ Further, low socioeconomic status was associated with a higher prevalence of dental caries. ${ }^{51,63}$ A national-level study done in Colombia that looked at the association of different socioeconomic-position dimensions and oral health found that those who lacked national-health insurance and those with lower education levels showed the highest oral health problems. ${ }^{64}$

Cross-sectional studies conducted in Chile in 2-4-year-old and 4-year-old children, ${ }^{65}$ as well as in Colombia in 8-71-month-old children, ${ }^{46}$ and in Mexico in 3-6-year-old children ${ }^{61}$ showed that older age was associated with an increased relevance and severity of caries.

Table 1 shows some studies with respect to the socioeconomic and demographic risk factors and caries in Latin America.

\section{Behavioral risk factors}

Behavioral risk factors include dietary practices, mainly high intake of free sugars, lack of oral hygiene, inadequate exposure to fluoride with emphasis on non-use of fluoride toothpaste, and irregular preventive dental care.

\section{Dietary practices}

The consumption of free sugars (i.e., sugars added to food and beverages and sugars naturally present in honey, syrups, fruit juices, and fruit juice concentrates) is the key factor that governs the occurrence of caries and modulates other factors, such as the dental biofilm. ${ }^{73,74}$ There is evidence that the following two characteristics enhance the role of dietary practices in the trajectory of caries incidence: the age at which sugar is introduced and the frequency of sugar consumption. Cohort studies have shown an association between

Table 1. Investigations regarding socioeconomic and demographic risk factors of dental caries in LACC according to age group.

\begin{tabular}{|c|c|c|c|c|c|c|}
\hline Author & Study design & Country & Age group & $\begin{array}{l}\text { Age (months-m } \\
\text { /years-y) }\end{array}$ & $\begin{array}{l}\text { Sample } \\
\text { size }\end{array}$ & Main result \\
\hline Martignon et al., $2018^{48}$ & Cross-sectional & $\begin{array}{l}\text { Anapoima, } \\
\text { Colombia }\end{array}$ & \multirow{8}{*}{ Children } & $8-71 \mathrm{~m}$ & 316 & $\begin{array}{l}\text { Older age and caregivers' low-level } \\
\text { education associated with caries. }\end{array}$ \\
\hline Zaror et al., $2011^{65}$ & Cross-sectional & Chile & & $2-4$ y & 301 & Older age associated with caries. \\
\hline $\begin{array}{l}\text { Guizar-Mendoza et al., } \\
2019^{61}\end{array}$ & Cross-sectional & $\begin{array}{l}\text { Bajo León, } \\
\text { Mexico }\end{array}$ & & $3-6$ y & 292 & $\begin{array}{l}\text { Older age and parents' low-level } \\
\text { education associated with caries. }\end{array}$ \\
\hline Feldens et al., $2010^{66}$ & Cohort & $\begin{array}{l}\text { São Leopoldo, } \\
\text { Brazil }\end{array}$ & & 4 y & 340 & $\begin{array}{l}\text { Mothers' low-level education } \\
\text { associated with caries. }\end{array}$ \\
\hline Montes et al., $2019^{67}$ & Cross-sectional & Curitiba, Brazil & & $4-5$ y & 415 & $\begin{array}{l}\text { Caregiver's oral health literacy } \\
\text { associated with caries. }\end{array}$ \\
\hline Herrera et al., $2013^{68}$ & Cross-sectional & Nicaragua & & $6-9$ y & 794 & Age associated with caries. \\
\hline Brito et al., $2020^{26}$ & Cross-sectional & $\begin{array}{l}\text { São Paulo, } \\
\text { Brazil }\end{array}$ & & $12 y$ & 26,325 & $\begin{array}{l}\text { Non-white ethnicity associated } \\
\text { with a higher caries prevalence. }\end{array}$ \\
\hline Freire et al., $2013^{69}$ & Cross-sectional & Brazil & & $12 y$ & 7,247 & $\begin{array}{l}\text { Low income and non-white } \\
\text { ethnicity associated with a higher } \\
\text { caries prevalence. }\end{array}$ \\
\hline $\begin{array}{l}\text { Solis-Riggioni et al., } \\
2018^{70}\end{array}$ & Cross-sectional & Costa Rica & \multirow{3}{*}{$\begin{array}{l}\text { Children and } \\
\text { Adolescents }\end{array}$} & $2-17$ y & 201 & $\begin{array}{c}\text { Socioeconomic factors associated } \\
\text { with caries. }\end{array}$ \\
\hline $\begin{array}{l}\text { Díaz-Cardenas et al., } \\
2010^{60}\end{array}$ & Cross-sectional & $\begin{array}{l}\text { Cartagena, } \\
\text { Colombia }\end{array}$ & & $4-13 y$ & 243 & $\begin{array}{l}\text { Parents' low-level education } \\
\text { associated with caries. }\end{array}$ \\
\hline $\begin{array}{l}\text { Casanova-Rosado et al., } \\
2005^{63}\end{array}$ & Cross-sectional & $\begin{array}{l}\text { Campeche, } \\
\text { Mexico }\end{array}$ & & $6-13 y$ & 1,806 & $\begin{array}{l}\text { Low socio-economic status, older age } \\
\text { and mother's low-level education } \\
\text { level associated with caries. }\end{array}$ \\
\hline $\begin{array}{l}\text { Echevarria-Lopez et al., } \\
2020^{62}\end{array}$ & Cross-sectional & Chile & $\begin{array}{l}\text { Adolescents } \\
\text { and Adults }\end{array}$ & $17-18$ y & 405 & $\begin{array}{l}\text { Mother's low-level education } \\
\text { associated with caries. }\end{array}$ \\
\hline Urzua et al., $2012^{71}$ & Cross-sectional & $\begin{array}{l}\text { Cartagena, } \\
\text { Colombia }\end{array}$ & \multirow{2}{*}{$\begin{array}{l}\text { Adults and } \\
\text { Elderly }\end{array}$} & $\begin{array}{l}35-44 \text { y } \\
65-74 \text { y }\end{array}$ & 1,088 & $\begin{array}{l}\text { Age, education level and incomes } \\
\text { associated with caries. }\end{array}$ \\
\hline Álvarez et al., $2013^{72}$ & Cross-sectional & Uruguay & & $\begin{array}{l}35-44 \text { y } \\
65-74 \text { y }\end{array}$ & 769 & $\begin{array}{l}\text { Low socio-economic status was } \\
\text { associated with caries. }\end{array}$ \\
\hline
\end{tabular}


sugar consumption in the first year of life and the occurrence of dental caries in subsequent years. ${ }^{75}$ The early introduction of sucrose in the life of an infant promotes the establishment of a cariogenic microbiota and successive colonization of new dental surfaces. Moreover, early exposure to sugar boosts a child's preference for sweets, resulting in higher consumption of sugar in foods and beverages. ${ }^{76}$

Investigations involving different populations have shown the role of high frequency of sugar intake in the occurrence of caries. ${ }^{66,74,77,78}$ There is a dose-dependent response between the ingestion of carbohydrates and dental caries in children and adults; with a greater intake of carbohydrates, especially sugar, increasing the risk of caries. This association is established by the repeated production of acids and the maintenance of a very low $\mathrm{pH}$ in the dental biofilm; this is observed in children with high food intake, impeding the physiological replacement of minerals in the de-mineralization/ re-mineralization cycle.

Some studies have examined the effect of two specific dietary practices on the occurrence of caries in children. Breastfeeding lowers child morbidity and mortality and appears to exert a protective effect against the occurrence of caries in the first year of life. However, birth cohort studies controlling for sugar intake have shown a greater risk of caries in infants who breastfeed for $>12$ months of life and with a high frequency ${ }^{79}$ Moreover, studies have shown that the use of bottles, especially for sugary beverages at night, was associated with dental caries. ${ }^{66}$ Increased risk of caries is related to the sugar content (generally sugar-sweetened beverages) and its accumulation on the biofilm on central incisors that are the most affected teeth in younger children. The cariogenicity of both practices is dependent on the frequency of added sugar consumption. Such sugar is usually offered as a pacifier, mainly at night, when the salivary flow is lower.

In children and adolescents, greater consumption of added sugar increases the risk and occurrence of caries. ${ }^{74}$ The risk of caries is lower when the daily consumption of free sugars is reduced to $<10 \%$ of the total energy. Moderate evidence shows that the amount and frequency of sugar intake are correlated: children and adolescents who eat sugar frequently tend to consume a large amount of sugar. ${ }^{80}$

\section{Oral hygiene and fluoride toothpaste}

Oral hygiene measures aim to remove the dental biofilm, the metabolic activity of which can result in the loss of minerals. Therefore, an increase in the risk of caries in children who do not practice tooth brushing is plausible. However, the quality of the disturbance of the biofilm seems relevant, although a recent systematic review does not show any conclusive evidence on the effectiveness of supervised tooth brushing on caries incidence. ${ }^{81}$ Biofilm removal could interact with the diet, as shown in an epidemiological study in children where a higher caries risk was associated with increasing levels of biofilm at all levels of sugar intake, suggesting a synergistic interaction between these two behavioral factors. ${ }^{82}$ Furthermore, most people do not remove dental biofilm completely during tooth brushing. Thus, the amount of fluoride retained in the biofilm during tooth brushing is involved in caries control. ${ }^{83}$

Brushing is a simple and cost-effective way of constantly supplying fluoride to the oral cavity. ${ }^{84,85}$ However, brushing with a non-fluoridated toothpaste is associated with a higher incidence of caries in children, adolescents, and adults. ${ }^{81,86}$ Thus, individuals who combine regular tooth brushing with fluoridated toothpaste have a lower risk of dental caries. ${ }^{87}$ There is no clinical evidence of a higher reduction in the risk of caries when the brushing frequency is $>2$ times a day, ${ }^{88}$ while there is a higher reduction in the risk of caries with increased fluoride concentration in the toothpaste. ${ }^{87}$

A recent critical review conducted in Latin America has shown that one of the most common risk indicators for gingivitis is poor oral hygiene, ${ }^{89}$ further highlighting the importance of oral hygiene.

\section{Regular preventive dental care}

Regular dental care combines individual behavioral factors with public-policy contextual factors (Figure 1). Absence of regular preventive dental care is associated with a higher number of fillings ${ }^{90}$ and poor oral health ${ }^{47}$ in adulthood.

The behaviour of attending regularly has been linked to keeping teeth healthy. ${ }^{91}$ There is a trend to move toward extended recall intervals and individualized preventive care as per the caries 
risk. ${ }^{92-94}$ In this context, periodic application of fluoride varnish (or gel) has a substantial caries-inhibiting effect in both, permanent and primary teeth ${ }^{95,96}$. Although not sufficiently established, the interval of dental visits depends on the risk classification of the patient in addition to age. It can vary from 3 months (in higher caries risk) to 12 and 24 months (in lower caries risk) in children and adults, respectively. ${ }^{92,93,97}$

\section{Behavioral factors in populations from} Latin America

Studies conducted in Brazil, Chile, and Colombia show that most children in different Latin American communities have access to foods with added sugars in the first two years of life and consume these foods with high frequencies and quantities during early childhood (Table 2). A study involving a representative, multinational sample of adolescents and adults from eight Latin American countries (Argentina, Brazil, Chile, Colombia, Costa Rica, Ecuador, Peru, and Venezuela) showed a high frequency of excessive added sugar intake, with minimal differences among the countries. ${ }^{98}$ In contrast, the practice of brushing teeth with fluoridated dentifrices has been widespread in Latin American countries since childhood.99-102 However, some studies have suggested that this habit begins later and occurs less frequently among families with lower socioeconomic status. ${ }^{103-105}$

Table 2 shows some trials on the behavioral risk factors and caries in LACC.

\section{Clinical implications}

Knowledge on behavioral caries risk factors suggests that delaying the introduction of sugar in the first years of life; reducing the frequency of consumption throughout life; and exposing children, adolescents, and adults to tooth brushing with a fluoridated toothpaste are potential interventions for reducing the burden of this disease. Excess sugar intake is also a risk factor for cardiovascular disease, diabetes, and obesity; ${ }^{, 20,121}$ therefore, reducing its consumption in individuals should be a goal for all health professionals. The adoption of healthier eating habits does not depend only on behavioral change. Eating practices are also influenced by advertising and food availability at supermarkets and schools.
In Latin America, Chile, Peru, Uruguay, and Mexico have nutrient warning policies for reducing sugar intake, recognizing it as a threat to human health. ${ }^{122}$

\section{Biological factors}

This group of caries risk factors comprises recent caries experience and active caries lesions, saliva, cariogenic biofilm, plaque stagnation areas, and developmental defects of the enamel.

Both, systematic and narrative reviews have reported that caries experience is the best predictor for the development of caries lesions in the future, ${ }^{123-129}$ with moderate to good accuracy in preschool children and limited accuracy in school children/adolescents. ${ }^{123,124}$ As a single-risk factor, past or active caries has been classified as strong evidence-based recommendation. ${ }^{127}$ Further, the highest caries incidence risk in permanent teeth is seen in the first few years after tooth eruption. ${ }^{130,131}$

Saliva is the most important biological factor involved in the protection against dental caries for several reasons, as follows: a) its buffering capacity restores the dental biofilm $\mathrm{pH}$ when the bacteria produce acids; b) salivary flow rate removes the acids from the oral cavity; c) it is supersaturated with calcium and phosphate with respect to the enamel mineral, thus promoting dental re-mineralization under favorable conditions; d) salivary proteins are the main components of the acquired enamel pellicle that acts as a semipermeable barrier, reducing the contact of the acids with the teeth. ${ }^{132,133}$ Thus, hyposalivation is related to dental caries. ${ }^{134}$ Some systemic and metabolic disorders, such as Sjögren's syndrome, medications, and head and neck irradiation, may cause salivary hypofunction, increasing the risk of caries. ${ }^{91,135,136}$

The oral microbiota on clinically sound enamel surfaces comprises mainly non-mutans streptococci and Actinomyces. In this case, acidification is mild and uncommon, and there is an equilibrium between de- mineralization and re-mineralization or a shift toward re-mineralization. With frequent sugar consumption, there is increased acid formation that changes the composition of the microbiota, increasing acidogenic and aciduric bacteria (mutans streptococci, 
Table 2. Investigations regarding behavioral factors and dental caries in LACC according to age group.

\begin{tabular}{|c|c|c|c|c|c|c|}
\hline Author & Study design & Country & Age group & $\begin{array}{l}\text { Age (months-m } \\
\text { /years-y) }\end{array}$ & $\begin{array}{l}\text { Sample } \\
\text { size }\end{array}$ & Main result \\
\hline $\begin{array}{l}\text { Lopez del Valle et al., } \\
1998^{105}\end{array}$ & Cross-sectional & Puerto Rico & \multirow{14}{*}{ Children } & $6-47 m$ & 167 & $\begin{array}{c}\text { Night bottle, persons, F- dentifrice \& child's } \\
\text { age associated with caries. }\end{array}$ \\
\hline $\begin{array}{l}\text { Hoffmeister et al., } \\
2016^{106}\end{array}$ & Cross-sectional & $\begin{array}{l}\text { Southern } \\
\text { Chile }\end{array}$ & & $2-4$ y & 2,987 & $\begin{array}{l}\text { Sugary drinks high-frequency bedtime } \\
\text { consumption associated with caries. }\end{array}$ \\
\hline Ribeiro et al., $2017^{77}$ & Cohort & $\begin{array}{l}\text { São Luís, } \\
\text { Brazil }\end{array}$ & & $2-5$ y & 388 & $\begin{array}{l}\text { High frequency of sugar consumption } \\
\text { associated with caries. }\end{array}$ \\
\hline $\begin{array}{l}\text { Macias et al., } \\
2016^{107}\end{array}$ & Cross-sectional & Colombia & & $24-60 m$ & 546 & $\begin{array}{l}\text { Dental visits, treatment, oral hygiene, diet \& } \\
\text { malnutrition associated with caries. }\end{array}$ \\
\hline Feldens et al., $2018^{78}$ & Cohort & $\begin{array}{l}\text { Porto Alegre, } \\
\text { Brazil }\end{array}$ & & $3 y$ & 345 & High frequency feeding associated with caries. \\
\hline Percival et al, $2019^{108}$ & Cross-sectional & $\begin{array}{l}\text { Trinidad \& } \\
\text { Tobago }\end{array}$ & & $3-5$ y & 342 & $\begin{array}{c}\text { Bottle feeding and high plaque levels } \\
\text { associated with caries. }\end{array}$ \\
\hline Feldens et al., $2010^{66}$ & Cohort & $\begin{array}{l}\text { São Leop., } \\
\text { Brazil }\end{array}$ & & 4 y & 340 & High density of sugar associated with caries. \\
\hline Melo et al., $2019^{109}$ & Cohort & Recife, Brazil & & $5-7$ y & 469 & Consumption of sweets associated with caries. \\
\hline $\begin{array}{l}\text { Ramón-Jimenez } \\
\text { et al., } 2016^{110}\end{array}$ & Cross-sectional & Cuba & & $5-11$ y & 300 & $\begin{array}{c}\text { Poor oral hygiene and dental crowding } \\
\text { associated with caries. }\end{array}$ \\
\hline Herrera et al., $2013^{68}$ & Cross-sectional & Nicaragua & & $6-9$ y & 794 & Biofilm and toothbrushing associated with caries. \\
\hline $\begin{array}{l}\text { Cipriano-Martinez; } \\
\text { Chipana-Herquinio, } \\
2017^{111}\end{array}$ & Cross-sectional & Perú & & $6-12$ y & 129 & Poor oral hygiene associated with caries. \\
\hline $\begin{array}{l}\text { García Pérez et al., } \\
2019^{112}\end{array}$ & Cross-sectional & $\begin{array}{l}\text { Mexico, } \\
\text { Mexico }\end{array}$ & & $8-12$ y & 522 & More sweets per day associated with caries. \\
\hline $\begin{array}{l}\text { Bedos; Brodeur, } \\
2000^{113}\end{array}$ & Cross-sectional & Haiti & & $12 y$ & 322 & $\begin{array}{c}\text { Dental hygiene and sugar intake associated } \\
\text { with caries. }\end{array}$ \\
\hline $\begin{array}{l}\text { Palacios et al., } \\
2016^{114}\end{array}$ & Cross-sectional & Puerto Rico & & $12 y$ & 1,587 & $\begin{array}{l}\text { Carbohydrates, sugars, sucrose, fructose / } \\
\text { inositol intake associated with caries. }\end{array}$ \\
\hline $\begin{array}{l}\text { Fernandez-Vega } \\
\text { et al., } 2014^{115}\end{array}$ & Cross-sectional & Venezuela & $\begin{array}{l}\text { Children and } \\
\text { Adolescents }\end{array}$ & $12-14 y$ & 240 & $\begin{array}{l}\text { Scarce brushing and rich-carbohydrate foods } \\
\text { ingestion associated with caries. }\end{array}$ \\
\hline $\begin{array}{l}\text { Arrieta-Vargas et al., } \\
2019^{116}\end{array}$ & Cross-sectional & $\begin{array}{l}\text { Guerrero, } \\
\text { Mexico }\end{array}$ & Adolescents & $15 y$ & 1,424 & $\begin{array}{c}\text { Intake of snacks, sweets, and soft drinks } \\
\text { associated with caries. }\end{array}$ \\
\hline $\begin{array}{l}\text { Carmo et al., } \\
2018^{117}\end{array}$ & Cross-sectional & $\begin{array}{l}\text { São Luís, } \\
\text { Brazil }\end{array}$ & $\begin{array}{l}\text { Adolescents } \\
\text { and Adults }\end{array}$ & $17-18$ y & 405 & Added sugar consumption associated with caries. \\
\hline Peres et al., $2016^{74}$ & Cohort & $\begin{array}{l}\text { Pelotas, } \\
\text { Brazil }\end{array}$ & Adults & $18 y$ & 307 & $\begin{array}{l}\text { The higher the sugar consumption along } \\
\text { adolescence, the higher the caries increment. }\end{array}$ \\
\hline $\begin{array}{l}\text { Rivera-Cruz et al., } \\
2017^{118}\end{array}$ & Cross-sectional & Cuba & $\begin{array}{l}\text { Adolescents, } \\
\text { Adults and } \\
\text { Elderly }\end{array}$ & $15-69$ y & 352 & $\begin{array}{c}\text { Poor oral hygiene and cariogenic diet } \\
\text { associated with caries. }\end{array}$ \\
\hline $\begin{array}{l}\text { Diaz-Sanchez, et al., } \\
2018^{119}\end{array}$ & Cross-sectional & Cuba & Elderly & Elderly & 166 & $\begin{array}{c}\text { Poor oral hygiene and cariogenic diet } \\
\text { associated with caries. }\end{array}$ \\
\hline
\end{tabular}

Only studies with samples $\geq 100$ participants were included.

lactobacilli, bifidobacteria, and yeasts). The net result is the de-mineralization of enamel. ${ }^{137}$

Plaque stagnation areas increase the accumulation of dental biofilm. Consequently, recently erupted first permanent molars are at higher risk of occlusal caries within the first post-eruption year and second permanent molars within the second and third post-eruption years. ${ }^{124,138,139}$ This was confirmed in a study performed in Colombian on the first permanent molars of 6-year-old children and the first and second primary molars of 2-year-old children. ${ }^{139}$ In particular, Cortes et al. ${ }^{140}$ found an increased caries risk on the distal area of the first primary molar when the neighbor primary molar had a concave proximal-surface. 
Developmental defects of enamel (DDE) with areas of enamel loss or incomplete mineralization are considered as risk factors for caries related to dental biofilm stagnation. ${ }^{141}$ Systematic reviews have shown an association between DDE and caries in the primary ${ }^{142}$ and permanent dentition, respectively. ${ }^{143}$

Disabilities caused by a physical or intellectual deficiency, such as cerebral palsy and Down's Syndrome, respectively, may interfere with an individual's routine functions. They may have special needs for assisted tooth brushing, the lack of which can compromise their oral hygiene, increasing their caries risk. ${ }^{144}$ Older age is also related to an increased caries risk because of health deterioration and dependence on other people to perform oral hygiene practices. ${ }^{145}$
Table 3 shows some studies conducted in LACC that have reported an association between dental caries and biological factors.

\section{Individual caries risk assessment}

Dental caries is a non-communicable disease with a multifactorial etiology that shares risk factors with other highly prevalent non-communicable diseases, such as obesity, diabetes, and cardiovascular disease; sugar intake is one of these risk factors. ${ }^{97}$

The individual caries risk assessment (CRA) is the clinical process of classifying the probability that caries lesions will appear or progress if the conditions remain the same within a defined period. ${ }^{1,123}$ It relates to a patient-centered caries management to reduce the risk of caries. ${ }^{1}$ CRA is supported in a scientific causal

Table 3. Investigations regarding biological risk factors and caries in LACC according to age group.

\begin{tabular}{|c|c|c|c|c|c|c|}
\hline Author & Study design & Country & Age group & $\begin{array}{l}\text { Age } \\
\text { (months-m / } \\
\text { years-y) }\end{array}$ & $\begin{array}{l}\text { Sample } \\
\text { size }\end{array}$ & Main result \\
\hline $\begin{array}{l}\text { Cortes et al., } \\
2018^{139}\end{array}$ & Cohort & Colombia & \multirow{8}{*}{ Children } & $2-6$ y & 352 & $\begin{array}{l}\text { Erupting primary molars and erupting first } \\
\text { permanent molars associated with caries. }\end{array}$ \\
\hline $\begin{array}{l}\text { Cortes et al., } \\
2018^{140}\end{array}$ & Cohort & Colombia & & $3-4$ y & 52 & $\begin{array}{l}\text { A concave proximal-surface morphology } \\
\text { between primary molars associated with a } \\
\text { caries lesion in distal of the } 1^{\text {st }} \text { molar. }\end{array}$ \\
\hline $\begin{array}{l}\text { Segovia-Villanueva } \\
\text { et al., } 2006^{146}\end{array}$ & Cross-sectional & $\begin{array}{l}\text { Campeche, } \\
\text { Mexico }\end{array}$ & & $3-6$ y & 1,303 & $\begin{array}{c}\text { Presence of enamel defects associated } \\
\text { with caries. }\end{array}$ \\
\hline $\begin{array}{l}\text { Velasquez et al., } \\
2019^{147}\end{array}$ & Case-control & Venezuela & & $6 y$ & 36 & $\begin{array}{l}\text { Saliva buffering capacity, } \\
\text { calcium/ phosphate associated with caries. }\end{array}$ \\
\hline $\begin{array}{l}\text { Gambetta-Tessini } \\
\text { et al., } 2019^{148}\end{array}$ & Cross-sectional & Talca, Chile & & $6-12$ y & 577 & $\begin{array}{c}\text { MIH and HSPM associated with caries and } \\
\text { caries severity. }\end{array}$ \\
\hline $\begin{array}{l}\text { Casanova-Rosado } \\
\text { et al., } 2005^{63}\end{array}$ & Cross-sectional & Campeche, & & $6-13 y$ & 1,806 & Enamel defects associated with caries. \\
\hline $\begin{array}{l}\text { Taboada-Aranza } \\
\text { et al., } 2018^{149}\end{array}$ & Cross-sectional & Mexico & & $6-13 y$ & 194 & $\begin{array}{c}\text { Erupting first permanent molar associated } \\
\text { with caries. }\end{array}$ \\
\hline $\begin{array}{l}\text { Villanueva-Gutierrez } \\
\text { et al., } 2019^{150}\end{array}$ & Cross-sectional & Mexico & & $8-12$ y & 506 & $\begin{array}{c}\text { Moderate/severe MIH associated with } \\
\text { cavitated carious lesions. }\end{array}$ \\
\hline $\begin{array}{l}\text { Acevedo et al., } \\
2009^{151}\end{array}$ & Cross-sectional & Venezuela & \multirow{3}{*}{$\begin{array}{l}\text { Children and } \\
\text { Adolescents }\end{array}$} & $2-19$ y & 48 & $\begin{array}{l}\text { Biofilm S. mutans in caries-affected/free } \\
\text { children not associated with caries. }\end{array}$ \\
\hline $\begin{array}{l}\text { Lopez-Olvera et al., } \\
2018^{152}\end{array}$ & Cross-sectional & Mexico & & $3-15$ y & 42 & S. mutans in saliva associated with caries. \\
\hline $\begin{array}{l}\text { Cornejo et al., } \\
2008^{153}\end{array}$ & Cohort & $\begin{array}{l}\text { Cordova, } \\
\text { Argentina }\end{array}$ & & $5-14$ y & 46 & $\begin{array}{l}\text { Phosphorus/calcium levels associated } \\
\text { with caries. }\end{array}$ \\
\hline $\begin{array}{l}\text { Santos et al., } \\
2009^{154}\end{array}$ & Cross-sectional & Brazil & $\begin{array}{l}\text { Children, } \\
\text { Adolescents } \\
\text { and Adults }\end{array}$ & $2-21$ y & 65 & Cerebral palsy associated with caries. \\
\hline $\begin{array}{l}\text { Martinez-Pabón } \\
\text { et al., } 2013^{155}\end{array}$ & Cross-sectional & Colombia & $\begin{array}{l}\text { Adolescents } \\
\text { and Adults }\end{array}$ & $17-34$ y & 120 & $\begin{array}{c}\text { Calcium/phosphate concentration and } \\
\text { bacteria associated with caries. }\end{array}$ \\
\hline $\begin{array}{l}\text { Usuga-Vacca et al., } \\
2020^{145}\end{array}$ & Cross-sectional & Colombia & Elderly & $71-89$ y & 226 & $\begin{array}{c}\text { Exposed surfaces and coronal caries } \\
\text { associated with root caries. }\end{array}$ \\
\hline
\end{tabular}


relationship based on risk models, programs, or single predictors validated via prospective cohort studies. ${ }^{129}$ The extrapolation of findings from high-quality predictive studies to the dental practice should be performed cautiously. ${ }^{123}$

Although the best indicator of a patient developing caries in the future is previous caries experience, ${ }^{123,124}$ the scientific evidence of standardized CRA is still limited, ${ }^{123,124,129,130}$ therefore, multivariate risk assessment models are considered optimal for clinical practice because they overcome assessing dental caries risk with only single predictors. These models consider socioeconomic factors, general health, behavior, diet, oral hygiene, and clinical factors including saliva., $97,123,156-158$

CRA is considered a part of the best practices in caries management decision-making, including recall intervals, ${ }^{91,97,123,159}$ with desirable effects mostly overweighting the undesirable effects. ${ }^{160}$ The multivariate risk models have shown moderate to good accuracy for early childhood caries and lower accuracy for children, adolescents, ${ }^{123}$ and adults. ${ }^{157,158}$

Risk assessment models specifically developed for children aged $<6$ y include the Dundee Caries Risk Assessment Model (DCRAM) and MySmileBuddy. Those for older children, adolescents, and adults include the Cariogram (also for younger children), the Caries Management by Risk Assessment (CAMBRA), the National University of Singapore model (NUS), the Caries Risk Tool (CAT), PreViser, the Caries Risk Pyramid, the American Dental Association (ADA) caries risk tool, the DCRAM, and the American Association of Pediatric Dentistry model (AAPD). ${ }^{123,160,161}$

More recently, for individuals off all ages, the CariesCare International (CCI), derived from ICCMS, developed a caries risk assessment model by consensus, taking concepts from Cariogram, ADA, and CAMBRA, among others ${ }^{97}$ (Figure 5). The $\mathrm{CCI}$ individual risk assessment model considers protective factors, social/medical/behavioral risk factors, and clinical risk factors. Protective factors relate to the use of $\geq 1000 \mathrm{ppm}$ fluoridated toothpaste twice a day, dental preventive care, and accessible community fluoride. Social/medical/behavioral risk factors emphasize as the more relevant risk factor the presence of hyposalivation, followed by a high intake of free sugars, while clinical risk factors consider as a key risk factor a recent caries experience and/or the presence of active caries lesions.

CCI considers active caries lesions between smooth, occlusal and proximal tooth surfaces ${ }^{128}$ better reflections the metabolic activity in the biofilm. ${ }^{124}$ Active carious lesions can be categorized by using the clinical ICDAS-merged severity and activity criteria as follows: based on their severity - initial (ICDAS 1 and 2; non cavitated), -moderate (ICDAS 3 and 4; microcavity and underlying dentine shadow), and - extensive (ICDAS 5 and 6; cavitated), and based on their activity - active when initial/moderate carious lesions present as whitish/yellowish, opaque, rough to gentle probing, in a plaque stagnation area, and as extensive carious lesions when the dentine feels soft or leathery on gentle probing. ${ }^{97}$ Figure 6, depicts the ICDAS-merged severity and activity criteria. ${ }^{97} \mathrm{CCI}$ classifies the patient into the following two risk categories: "lower caries risk" or "higher caries risk," applying a simplified and practical version following a more ethical path, ${ }^{129}$ and highlighting clear best-practice management needs, including homecare, clinical approaches, and risk-based intervals (Figure 5).

\section{Clinical implications}

With regard to ECC, specific protocols focus on the urgency to reduce the risk of dental caries progression, determining the frequency of interventions, and the need to improve primary prevention. ${ }^{162}$ In all age groups, high consumption of free sugars should be avoided and brushing teeth twice every day with fluoridated

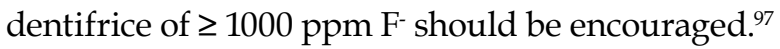

In the elderly, risk indicators that accurately predict root caries incidence include an increased number of exposed root surfaces and increased root caries experience, gingival recession, poor oral hygiene, and lower socioeconomic level. ${ }^{146,163,164}$

The caries risk status influences the treatment for specific tooth-surface carious lesions in permanent teeth in Colombian dentists, with operative care overruling non-operative care for an initial lesion in the presence of a higher risk of caries. ${ }^{165}$

Age should be considered for the CRA because it is related to individual changes and characteristics at different levels (Figure 3). The caries risk is modifiable 


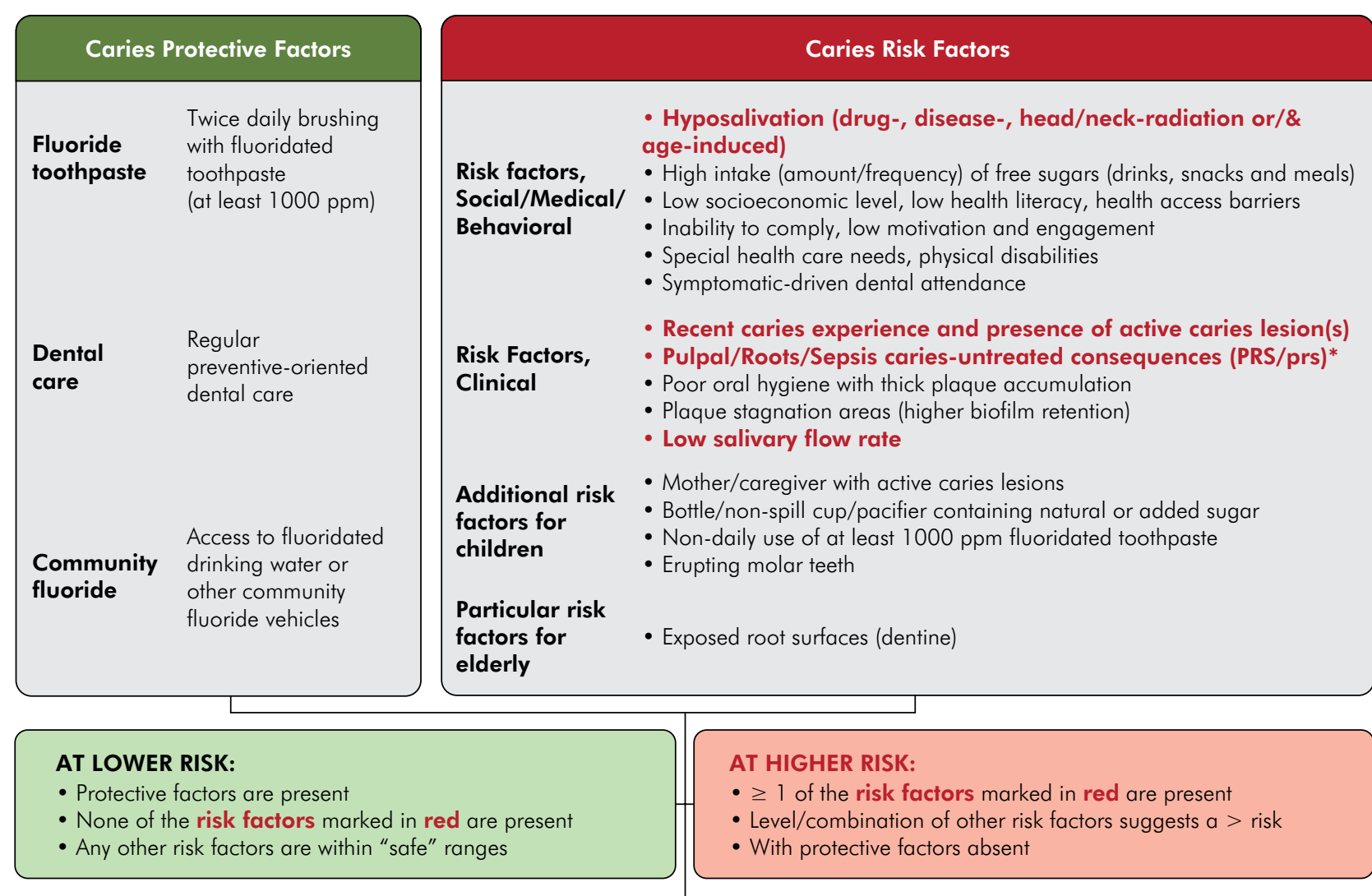

Management decision at the patient level

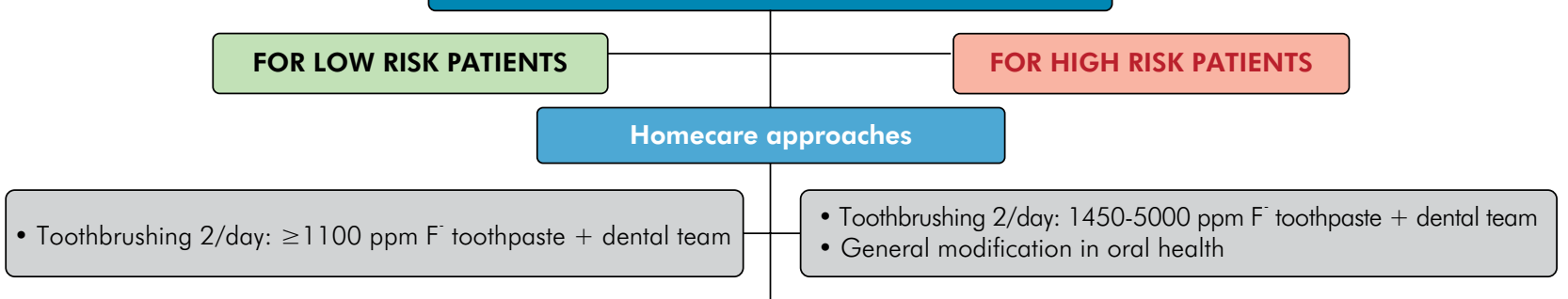

Clinical interventions/approaches

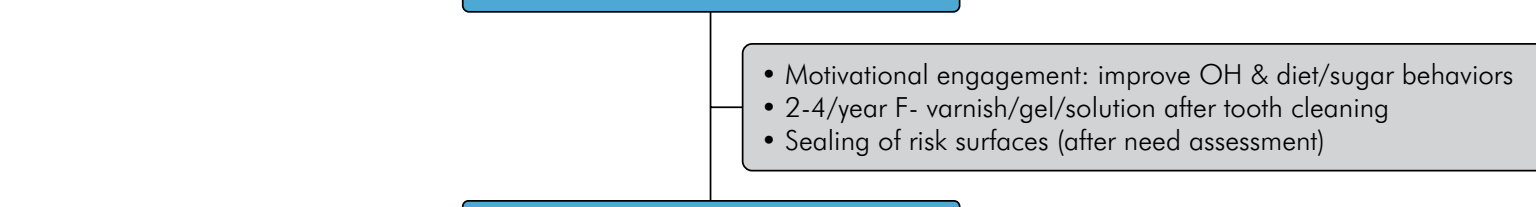

Risk-based intervals

Adults: 6-24 months. Children: 6-12 months

Adults \& Children: 3-6 months

*Pulpal Involvement-Roots-Sepsis Index: clinical consequences of untreated caries. P/p: caries process reached pulp chamber; Roots (R/r): caries process destroyed tooth structures (non-restorable); S/s: pus-releasing tract/tooth-related pus containing swelling.

Material created by the authors.

Figure 5. Individual caries risk assessment, classification, and management decision, adapted from CariesCare International. ${ }^{90}$

by clinical measures and behavioral changes as well as by individual characteristics; therefore, its assessment should be conducted for every patient during the oral health review. ${ }^{91,97}$ 


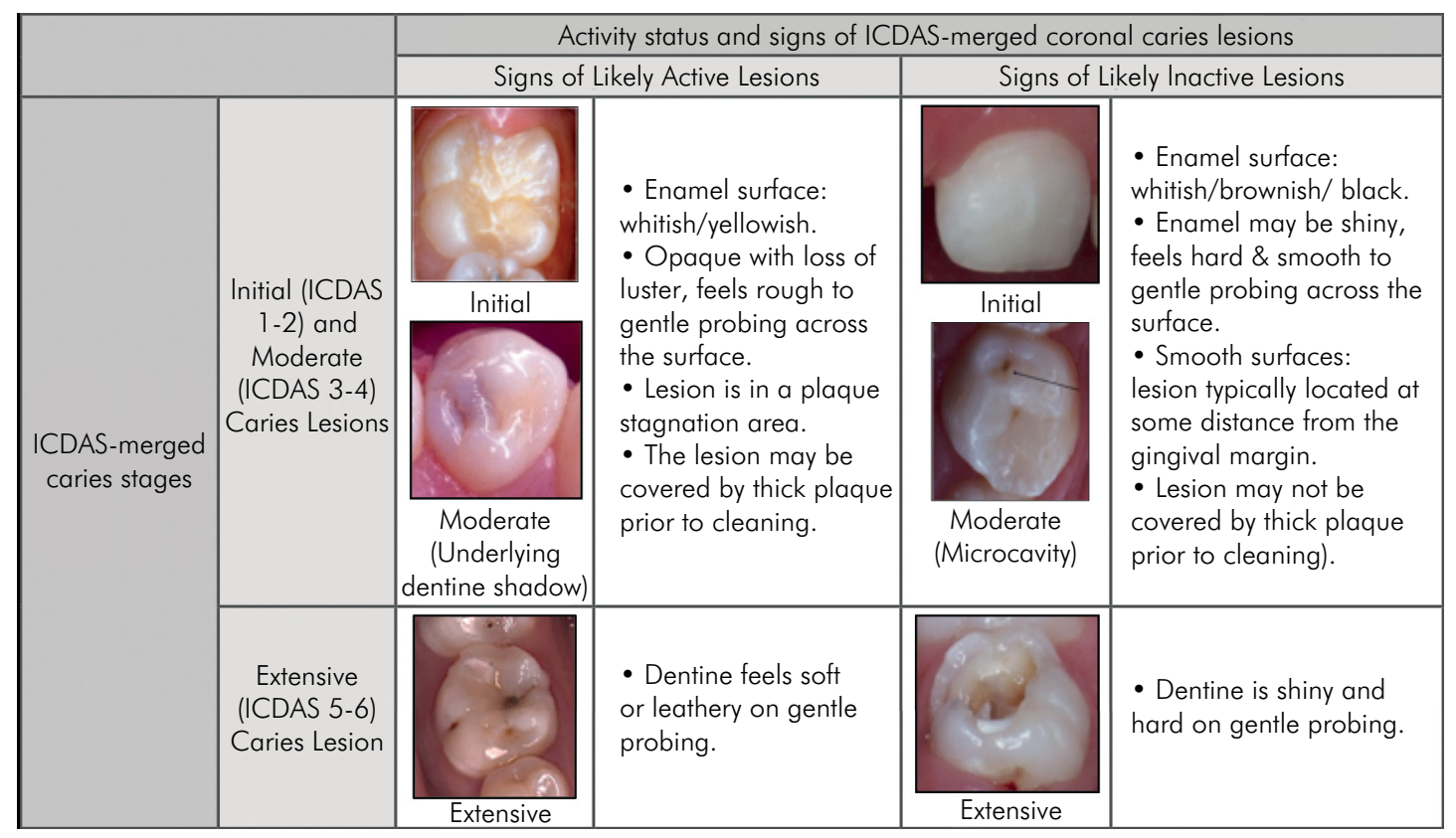

Material created by the authors.

Figure 6. Activity status and signs of ICDAS-merged coronal caries lesions, adapted from CariesCare International. 96

Risk assessment and management provides an opportunity to communicate with patients to enable them to adhere and reduce their caries risk, puts oral health into general health, and reinforces the oral health record legally. ${ }^{97}$

\section{Dental educational aspects related to CRA}

CRA in the core curriculum of dental students qualifies as a significant competency and is considered an essential component in the decision-making process for correct individual dental caries management. This implies a careful linkage between the teaching and learning processes of caries risk assessment, diagnosis, and synthesis domain, in both, the clinical decision-making and the non-operative and the operative care domains ${ }^{166}$. Evidence-based teaching in dentistry should permeate all aspects of the curriculum. In Spanish-speaking Latin American dental schools, Martignon et al. ${ }^{167}$ reported that while $87 \%$ dental schools teach caries risk assessment and preventive strategies, only $43 \%$ link both of these in the clinic.

In Colombia, after a consensus was achieved in cariology teaching for undergraduate students in 2012 among most dental schools (94\%), CRA was designated as a learning objective. ${ }^{168}$ This was also the case with the $100 \%$ consensus being achieved among 15 dental schools in the Caribbean region, 12 in the Dominican Republic, and 1 each in Puerto Rico, Jamaica, and Trinidad and Tobago. ${ }^{169}$ In Brazil, information about caries risk is disseminated via Public health and Integrated seminars, risk factors, and determinants ${ }^{170}$ and taught in a theoretical manner in most dental schools (94\%). ${ }^{171}$ In Chile, all universities teach CRA theoretically, ${ }^{172}$ with clinical application being taught at only $40 \%$ of all dental schools. ${ }^{173}$

Other data show that students exhibit relatively lower response to the usefulness of a CRA tool, such as Cariogram in the planning of treatments linked to the relatively low knowledge of part-time faculty in using this tool. ${ }^{174}$ Calibration training for both, teachers and students may help resolve this issue. ${ }^{175,176}$

\section{General Implications for public health policies}

The correct identification of risk factors for dental caries has a direct implication in the implementation of public policies. It allows the organization of oral health services directed at the population that needs it the most. Thus, health policies based on the principles of equity in health care are required. Unfortunately, LACC do not have universal health systems, and 
oral health, in turn, is offered in most cases through private health care facilities.

In countries with more consolidated public health systems, oral health policies must use the concept of risk factors beyond the individual level. Ideally, caries risk factors should be embedded in a broader context that includes other preventive strategies in an inter-sectorial perspective. The strategy of common risk factors ${ }^{42}$ indicates the need of articulating health education policies for different areas of health. Oral diseases share risk factors with other systemic diseases, such as obesity, diabetes, and cancer; therefore, the adoption of collaborative strategies becomes more rational. In paper 3 of this LAOHA caries consensus, Ricomini-Filho et al. discusses oral public health alternatives in more detail. ${ }^{40}$

\section{General Implications for clinical practice}

Considering the available scientific evidence and best practices, caries management at the individual level relates to patient-centered practices wherein risk-based care is highlighted. ${ }^{93}$ Despite a low-to-moderate evidence of CRA models and the difficulties in the extrapolation of studies, advantages overcome the disadvantages. There is an agreement for risk assessment, with preference of a multi-factor model over a single factor assessment, involving protective and risk factors, putting oral health into general health, considering the common risk factors' strategy, and leading caries risk management to homecare and in-office approaches with a risk-linked interval recall. More recently, there is a trend to simplify the caries risk classification into the following two categories: higher and lower, to facilitate effective management. The involvement of patients in their oral health care is benefited by the dental team-patient communication through CRA; becoming aware of their disease risk increases the patients' adherence and satisfaction with dental care. In paper 4 of this LAOHA caries consensus, Pozos-Guillén et al. ${ }^{176}$ discusses individual caries care alternatives at the tooth level in more detail.

\section{Conclusions and recommendations - Perspectives for LACC}

Identifying modifiable risk factors for dental caries should be the basis for multi-strategy actions that consider the historical, ethnic, and cultural diversity of LACC communities.

This includes general measures that address social determinants and specific oral health measures such as:

a. increasing the education level;

b. increasing oral health literacy;

c. reducing poverty and inequality;

d. endorsing community fluoridation policies;

e. supporting upstream measures that promote the reduction of sugar intake, such as policies on advertising, availability, and taxation of sugary products;

f. encouraging healthy dietary practices and discouraging the consumption of free sugars from childhood to adulthood;

g. promoting tooth brushing with $\geq 1000 \mathrm{ppm}$ fluoride-containing toothpaste for all children, adolescents, and adults;

h. promoting patient-centered and risk-based caries care;

i. promoting integrated actions among the dental team and other health care professionals.

Integrated actions among dentists, other health professionals, and policymakers represent the only option for effectively combating the common risk factors to reduce the burden of dental caries and other non-communicable diseases. Moreover, there is a need to conduct higher -quality studies in LACC to achieve a better understanding in our populations regarding the effect of exposures to caries risk factors on dental caries, within the framework of non-communicable disease related to oral health, general health, and quality of life. Peres et al., ${ }^{47}$ highlighted the need for birth cohort studies, epidemiologic and statistical analyses, observational and nested intervention studies, as well as conforming collaborative group studies.

\section{Acknowledgments}

This paper was prepared for the consensus meeting titled "Dental Caries Prevalence, Prospects and Challenges for LACC", promoted by the Latin American Oral Health Association and Colgate Palmolive Co. with the support of the Federación Odontológica Latinoamericana, Sociedade Brasileira de 
Pesquisa Odontológica (SBPqO/Brazilian Division of IADR), and the participation of experts from the region, including representatives from national, regional and international dental associations. All participants had the opportunity to review the manuscript and make their own contributions. This paper contributed to the summary and final recommendations of the Dental Caries Regional Consensus.

\section{References}

1. Machiulskiene V, Campus G, Carvalho JC, Dige I, Ekstrand KR, Jablonski-Momeni A, et al. Terminology of dental caries and dental caries management: Consensus Report of a Workshop Organized by ORCA and Cariology Research Group of IADR. Caries Res. 2020;54(1):7-14. https://doi.org/10.1159/000503309

2. Fejerskov $O$, Nyvad B, Kidd EA. Chapter 2: Dental caries: what is it? In: Fejerskov $O$, Nyvad B, Kidd E, editors. Dental caries: the disease and its clinical management. 3rd ed. Oxford: Wiley Blackwell; 2015.

3. Opal S, Garg S, Jain J, Walia I. Genetic factors affecting dental caries risk. Aust Dent J. 2015 Mar;60(1):2-11. https://doi.org/10.1111/adj.12262

4. Fernando S, Speicher DJ, Bakr MM, et al. Protocol for assessing maternal, environmental and epigenetic risk factors for dental caries in children. BMC Oral Health. 2015;15:167. https://doi.org/10.1186/s12903-015-0143-2

5. Silva AM, Gkolia P, Carpenter L, Cole D. Developing a model to assess community-level risk of oral diseases for planning public dental services in Australia. BMC Oral Health. 2016;16:45. Published 2016 Mar 31. https://doi.org/10.1186/s12903-016-0200-5

6. Foley M, Akers HF. Does poverty cause dental caries? Aust Dent J. 2019 Mar;64(1):96-102. https://doi.org/10.1111/adj.12666

7. Dahlgren G, Whitehead M. Policies and strategies to promote social equity in health: background document to WHO - Strategy paper for Europe. Stockholm: Institute for Futures Studies; 1991.

8. Tomar S. Social determinants of oral health and disease in U.S. men. J Men's Health. 2012;9(2):113-9. https://doi.org/10.1016/i.jomh.2012.03.001

9. Fisher-Owens SA, Gansky SA, Platt LJ, Weintraub JA, Soobader MJ, Bramlett MD, et al. Influences on children's oral health: a conceptual model. Pediatrics. 2007 Sep;120(3):e510-20. https://doi.org/10.1542/peds.2006-3084

10. Smith L, Katz L, Emery H, Sieppert J, Polsky Z, Nagan K. It's about More Than Just Baby Teeth: An Examination of Early Oral Care in Canada. Univers J Public Health. 2014;2(4):125-30. https://doi.org/10.13189/ujph.2014.020403

11. Crall JJ, Forrest CB. A life course health development perspective on oral health. In: Halfon N, Forrest CB, Lerner RM, et al. Handbook of life course health development. Springer; 2018.

12. World Health Organization. A conceptual framework for action on the social determinants of health. Geneva: WHO; 2010.

13. Paiva SM, Abreu-Placeres N, Camacho MEI, Frias AC, Tello G, Perazzo MF, et al. Dental caries experience and its impact on oral health-related quality of life in Latin American and Caribbean countries. Braz Oral Res. 2021;35(suppl 1):e052. https://doi.org/10.1590/1807-3107bor-2021.vol35.0052

14. Sampaio FC, Bönecker M, Paiva SM, Martignon S, Ricomini Filho AP, Pozos-Guillen A, et al. Dental caries prevalence, prospects, and challenges for Latin America and Caribbean countries: a summary and final recommendations from a Regional Consensus. Braz Oral Res. 2021;35(suppl 1):e056. https://doi.org/10.1590/1807-3107bor-2021.vol35.0056

15. Roncalli AG, Sheiham A, Tsakos G, Araújo-Souza GC, Watt RG. Social Factors Associated with the Decline in Caries in Brazilian Children between 1996 and 2010. Caries Res. 2016;50(6):551-9. https://doi.org/10.1159/000442899

16. Moysés SJ. Desigualdades em saúde bucal e desenvolvimento humano: um ensaio em preto, branco e alguns tons de cinza. Rev Bras Odont Saúde Coletiva. 2000;1:7-17.

17. Antunes JL, Peres MA, Mello TRC, Waldman EA. Multilevel assessment of determinants of dental caries experience in Brazil. Community Dent Oral Epidemiol. 2006 Apr;34(2):146-52. https://doi.org/10.1111/j.1600-0528.2006.00274.x

18. Gabardo MC, Silva WJ, Moysés ST, Moysés SJ. Water fluoridation as a marker for sociodental inequalities. Community Dent Oral Epidemiol. 2008 Apr;36(2):103-7. https://doi.org/10.1111/j.1600-0528.2007.00381.x

19. Peres MA, Peres KG, Antunes JL, Junqueira SR, Frazão P, Narvai PC. The association between socioeconomic development at the town level and the distribution of dental caries in Brazilian children. Rev Panam Salud Publica. 2003 Sep;14(3):149-57. https://doi.org/10.1590/S1020-49892003000800001

20. Peres MA, Peres KG, Frias AC, Antunes JL. Contextual and individual assessment of dental pain period prevalence in adolescents: a multilevel approach. BMC Oral Health. 2010;10:20. https://doi.org/10.1186/1472-6831-10-20

21. Roncalli AG, Tsakos G, Sheiham A, de Souza GC, Watt RG. Social determinants of dental treatment needs in Brazilian adults. BMC Public Health. 2014;14:1097. https://doi.org/10.1186/1471-2458-14-1097 
22. Pinto RS, Roncalli AG, Abreu MH, Vargas AM. Use of public oral health services by the adult population: a multilevel analysis. PLoS One. 2016;11(1):e0145149. https://doi.org/10.1371/journal.pone.0145149

23. Pessoa DMV, Roncalli AG, Lima KC. Economic and sociodemographic inequalities in complete denture need among older Brazilian adults: a cross-sectional population-based study. BMC Oral Health. 2017;17(1):5. https://doi.org/10.1186/s12903-016-0233-9

24. Silva JVD, Oliveira AGRDC. Individual and contextual factors associated to the self-perception of oral health in Brazilian adults. Rev Saude Publica. 2018;52:29. https://doi.org/10.11606/S1518-8787.2018052000361

25. Brito AC, Bezerra IM, Cavalcante DF, Pereira AC, Vieira V, Montezuma MF, et al. Dental caries experience and associated factors in 12-year-old-children: a population based-study. Braz Oral Res. 2020;34:e010. https://doi.org/10.1590/1807-3107bor-2020.vol34.0010

26. Ardila CM, Agudelo-Suárez AA. Association between dental pain and caries: a multilevel analysis to evaluate the influence of contextual and individual factors in 34843 adults. J Investig Clin Dent. 2016 Nov;7(4):410-6. https://doi.org/10.1111/jicd.12168

27. Bernabé $\mathrm{E}, \mathrm{Hobdell} \mathrm{MH}$. Is income inequality related to childhood dental caries in rich countries? J Am Dent Assoc. 2010 Feb;141(2):143-9. https://doi.org/10.14219/jada.archive.2010.0131

28. Guarnizo-Herreño CC, Watt RG, Pikhart H, Sheiham A, Tsakos G. Socioeconomic inequalities in oral health in different European welfare state regimes. J Epidemiol Community Health. 2013 Sep;67(9):728-35. https://doi.org/10.1136/jech-2013-202714

29. Guarnizo-Herreño CC, Watt RG, Garzón-Oriuela N, Tsakos G. Explaining oral health inequalities in European welfare state regimes: the role of health behaviours. Community Dent Oral Epidemiol. 2019 Feb;47(1):40-8. https://doi.org/10.1111/cdoe.12420

30. Drugan CS, Downer MC. [Dental health in the United Kingdom and influencing variables]. Bundesgesundheitsblatt Gesundheitsforschung Gesundheitsschutz. 2011 Sep;54(9):1027-34. German. https://doi.org/10.1007/s00103-011-1333-y

31. Nadanovsky P, Sheiham A. Relative contribution of dental services to the changes in caries levels of 12-year-old children in 18 industrialized countries in the 1970s and early 1980s. Community Dent Oral Epidemiol. 1995 Dec;23(6):331-9. https://doi.org/10.1111/j.1600-0528.1995.tb00258.x

32. Diehnelt DE, Kiyak HA. Socioeconomic factors that affect international caries levels. Community Dent Oral Epidemiol. 2001 Jun;29(3):226-33. https://doi.org/10.1034/i.1600-0528.2001.290309.x

33. Antunes JL, Narvai PC, Nugent ZJ. Measuring inequalities in the distribution of dental caries. Community Dent Oral Epidemiol. 2004 Feb;32(1):41-8. https://doi.org/10.1111/j.1600-0528.2004.00125.x

34. Ran T, Chattopadhyay SK. Economic evaluation of community water fluoridation: a community guide systematic review. Am J Prev Med. 2016 Jun;50(6):790-6. https://doi.org/10.1016/i.amepre.2015.10.014

35. Yeung CA. A systematic review of the efficacy and safety of fluoridation. Evid Based Dent. 2008;9(2):39-43. https://doi.org/10.1038/si.ebd.6400578

36. Iheozor-Ejiofor Z, Worthington HV, Walsh T, O'Malley L, Clarkson JE, Macey R, et al. Water fluoridation for the prevention of dental caries. Cochrane Database Syst Rev. 2015;2015(6):CD010856. Published 2015 Jun 18. https://doi.org/10.1002/14651858.CD010856.pub2

37. Marthaler TM. Salt fluoridation and oral health. Acta Med Acad. 2013 Nov;42(2):140-55. https://doi.org/10.5644/ama2006-124.82

38. Yengopal V, Chikte UM, Mickenautsch S, Oliveira LB, Bhayat A. Salt fluoridation: a meta-analysis of its efficacy for caries prevention. SADJ. 2010 Mar;65(2):60-4, 66-7.

39. Estupinan-Day S. Promoting oral health. The use of salt fluoridation to prevent dental caries. Washington, DC: Pan American Health Organization; 2005.

40. Ricomini Filho AP, Chávez BA, Giacaman RA, Frazão P, Cury JA. Community interventions and strategies for caries control in Latin American and Caribbean countries. Braz Oral Res. 2021;35(suppl 1):e054. https://doi.org/10.1590/1807-3107bor-2021.vol35.054

41. Cury JA, Caldarelli PG, Tenuta LM. Necessity to review the Brazilian regulation about fluoride toothpastes. Rev Saude Publica. 2015;49(0):74. https://doi.org/10.1590/S0034-8910.2015049005768

42. Watt RG, Sheiham A. Integrating the common risk factor approach into a social determinants framework. Community Dent Oral Epidemiol. 2012 Aug;40(4):289-96. https://doi.org/10.1111/j.1600-0528.2012.00680.x

43. Helman C. Culture, health, and illness: An introduction for health professionals. Bristol: Wright; 1984.

44. Blakely TA, Woodward AJ. Ecological effects in multi-level studies. J Epidemiol Community Health. 2000 May;54(5):367-74. https://doi.org/10.1136/jech.54.5.367

45. Krieger N. A glossary for social epidemiology. Epidemiol Bull. 2002 Mar;23(1):7-11. https://doi.org/10.1136/jech.55.10.693

46. Schwendicke F, Dörfer CE, Schlattmann P, Foster Page L, Thomson WM, Paris S. Socioeconomic inequality and caries: a systematic review and meta-analysis. J Dent Res. 2015 Jan;94(1):10-8. https://doi.org/10.1177/0022034514557546

47. Peres KG, Thomson WM, Chaffee BW, Peres MA, Birungi N, Do LG, et al. Oral Health Birth Cohort Studies: Achievements, Challenges, and Potential [published online ahead of print, 2020 Jul 17]. J Dent Res. 2020 Nov;99(12):1321-31. https://doi.org/10.1177/0022034520942208

48. Martignon S, Usuga-Vacca M, Cortés F, Cortes A, Gamboa LF, Jacome-Lievano S, et al. Risk factors for early childhood caries experience expressed by ICDAS criteria in Anapoima, Colombia: a cross-sectional study. Acta Odontol Latinoam. 2018 Jun;31(1):58-66. 
49. Solar O, Irwin A. A conceptual framework for action on the social determinants of health. Social Determinants of Health Discussion Paper 2: debates, policy \& practice, case studies. Geneva: WHO, 2010.

50. Hooley M, Skouteris H, Boganin C, Satur J, Kilpatrick N. Parental influence and the development of dental caries in children aged 0-6 years: a systematic review of the literature. J Dent. 2012 Nov;40(11):873-85. https://doi.org/10.1016/i.jdent.2012.07.013

51. Boing AF, Bastos JL, Peres KG, Antunes JL, Peres MA. Social determinants of health and dental caries in Brazil: a systematic review of the literature between 1999 and 2010. Rev Bras Epidemiol. 2014;17 Suppl 2:102-15. https://doi.org/10.1590/1809-4503201400060009

52. Firmino RT, Ferreira FM, Paiva SM, Granville-Garcia AF, Fraiz FC, Martins CC. Oral health literacy and associated oral conditions: A systematic review. J Am Dent Assoc. 2017 Aug;148(8):604-13. https://doi.org/10.1016/i.adaj.2017.04.012

53. Shaffer JR, Leslie EJ, Feingold E, Govil M, McNeil DW, Crout RJ, et al. Caries Experience Differs between Females and Males across Age Groups in Northern Appalachia. Int J Dent. 2015;2015:938213. https://doi.org/10.1155/2015/938213

54. Ferraro M, Vieira AR. Explaining gender differences in caries: a multifactorial approach to a multifactorial disease. Int J Dent. 2010;2010:649643. https://doi.org/10.1155/2010/649643 PMID:20339488

55. Martinez-Mier EA, Zandona AF. The impact of gender on caries prevalence and risk assessment. Dent Clin North Am. 2013 Apr;57(2):301-15. https://doi.org/10.1016/j.cden.2013.01.001

56. Tas JT, Kragt L, Veerkamp JJ, Jaddoe VW, Moll HA, Ongkosuwito EM, et al. Ethnic disparities in dental caries among six-year-old children in the Netherlands. Caries Res. 2016;50(5):489-97. https://doi.org/10.1159/000448663

57. Kaplan JB, Bennett T. Use of race and ethnicity in biomedical publication. JAMA. 2003 May;289(20):2709-16. https://doi.org/10.1001/jama.289.20.2709

58. Bernabé E, Sheiham A. Age, period and cohort trends in caries of permanent teeth in four developed countries. Am J Public Health. 2014 Jul;104(7):e115-21. https://doi.org/10.2105/AJPH.2014.301869

59. Soares GH, Pereira NF, Biazevic MG, Braga MM, Michel-Crosato E. Dental caries in South American Indigenous peoples: a systematic review. Community Dent Oral Epidemiol. 2019 Apr;47(2):142-52. https://doi.org/10.1111/cdoe.12436

60. Díaz-Cárdenas S, González-Martínez F. [The prevalence of dental caries related to family factors in schoolchildren from the city of Cartagena in Colombia]. Rev Salud Publica (Bogota). 2010 Oct;12(5):843-51. Spanish. https://doi.org/10.1590/S0124-00642010000500014

61. Guizar-Mendoza JM, López-Ayuso CA, Amado-Licona N, Lozano-Palomino O, García-Gutiérrez CA. [Determinants of oral health care related to the frequency and severity of dental caries in preschool children]. Nova Sci. 2019;11(22):85-101. Spanish. https://doi.org/10.21640/ns.v11i22.1708

62. Echeverria-López S, Henríquez-D'Aquino E, Werlinger-Cruces F, Villarroel-Díaz T, Lanas-Soza M. [Determinants of early childhood caries in children at social risk]. Int J Interdiscip Dent. 2020;13(1):26-9. Spanish. https://doi.org/10.4067/S2452-55882020000100026

63. Casanova-Rosado AJ, Medina-Solís CE, Casanova-Rosado JF, Vallejos-Sánchez AA, Maupomé G, Avila-Burgos L. Dental caries and associated factors in Mexican schoolchildren aged 6-13 years. Acta Odontol Scand. 2005 Aug;63(4):245-51. https://doi.org/10.1080/00016350510019865

64. Guarnizo-Herreño CC, Watt RG, Garzón-Oriuela N, Suárez-Zúñiga E, Tsakos G. Health insurance and education: major contributors to oral health inequalities in Colombia. J Epidemiol Community Health. 2019 Aug;73(8):737-44. https://doi.org/10.1136/jech-2018-212049

65. Zaror-Sánchez C, Pineda-Toledo P, Orellana-Cáceres JJ. [Prevalence of early childhood caries and associated factors in 2 and 4 year-old chilean children]. Int J Odontostomatol. 2011;5(2):171-7. https://doi.org/10.4067/S0718-381X2011000200010

66. Feldens CA, Giugliani ER, Vigo Á, Vítolo MR. Early feeding practices and severe early childhood caries in four-year-old children from southern Brazil: a birth cohort study. Caries Res. 2010;44(5):445-52. https://doi.org/10.1159/000319898

67. Montes GR, Bonotto DV, Ferreira FM, Menezes JV, Fraiz FC. Caregiver's oral health literacy is associated with prevalence of untreated dental caries in preschool children. Cien Saude Colet. 2019;24(7):2737-2744. https://doi.org/10.1590/1413-81232018247.18752017

68. Socorro Herrera MS, Medina-Solís CE, Minaya-Sánchez M, Pontigo-Loyola AP, Villalobo-Rodelo JJ, Islas-Granill H, et al. Dental plaque, preventive care, and tooth brushing associated with dental caries in primary teeth in schoolchildren ages 6-9 years of Leon, Nicaragua. Med Sci Monit. 2013;19:1019-1026. Published 2013 Nov 19. https://doi.org/10.12659/MSM.884025

69. Freire Mdo C, Reis SC, Figueiredo N, Peres KG, Moreira Rda S, Antunes JL. [Individual and contextual determinants of dental caries in Brazilian 12-year-olds in 2010]. Rev Saude Publica. 2013 Dec;47 Suppl 3:40-9. Portuguese. https://doi.org/10.1590/s0034-8910.2013047004322.

70. Solis-Riggioni A, Gallardo-Barquero C, Chavarria-Bolaños D. Prevalence and severity of dental caries in foster-care children and adolescents. J Clin Pediatr Dent. 2018;42(4):269-72. https://doi.org/10.17796/1053-4628-42.4.5

71. Urzua I, Mendoza C, Arteaga O, Rodríguez G, Cabello R, Faleiros S, et al. Dental caries prevalence and tooth loss in chilean adult population: first national dental examination survey. Int J Dent. 2012;2012:810170. https://doi.org/10.1155/2012/810170

72. Álvarez L, Liberman J, Abreu S, Mangarelli C, Correa MB, Demarco FF, et al. Dental caries in Uruguayan adults and elders: findings from the first Uruguayan National Oral Health Survey. Cad Saude Publica. 2015 Aug;31(8):1663-72. https://doi.org/10.1590/0102-311X00132214 
73. Moynihan PJ, Kelly SA. Effect on caries of restricting sugars intake: systematic review to inform WHO guidelines. J Dent Res. 2014 Jan;93(1):8-18. https://doi.org/10.1177/0022034513508954

74. Peres MA, Sheiham A, Liu P, Demarco FF, Silva AE, Assunção MC, et al. Sugar consumption and changes in dental caries from childhood to adolescence. J Dent Res. 2016 Apr;95(4):388-94. https://doi.org/10.1177/0022034515625907

75. Chaffee BW, Feldens CA, Rodrigues PH, Vítolo MR. Feeding practices in infancy associated with caries incidence in early childhood. Community Dent Oral Epidemiol. 2015 Aug;43(4):338-48. https://doi.org/10.1111/cdoe.12158

76. Ventura AK, Worobey J. Early influences on the development of food preferences. Curr Biol. 2013 May;23(9):R401-8. https://doi.org/10.1016/i.cub.2013.02.037

77. Ribeiro CC, Silva MC, Nunes AM, Thomaz EB, Carmo CD, Ribeiro MR, et al. Overweight, obese, underweight, and frequency of sugar consumption as risk indicators for early childhood caries in Brazilian preschool children. Int J Paediatr Dent. 2017 Nov;27(6):532-9. https://doi.org/10.1111/ipd.12292

78. Feldens CA, Rodrigues PH, Anastácio G, Vítolo MR, Chaffee BW. Feeding frequency in infancy and dental caries in childhood: a prospective cohort study. Int Dent J. 2018 Apr;68(2):113-21. https://doi.org/10.1111/idj.12333

79. Peres KG, Chaffee BW, Feldens CA, Flores-Mir C, Moynihan P, Rugg-Gunn A. Breastfeeding and Oral Health: Evidence and Methodological Challenges. J Dent Res. 2018 Mar;97(3):251-8. https://doi.org/10.1177/0022034517738925

80. Santos AP, Oliveira BH, Nadanovsky P. A systematic review of the effects of supervised toothbrushing on caries incidence in children and adolescents. Int J Paediatr Dent. 2018 Jan;28(1):3-11. https://doi.org/10.1111/ipd.12334

81. Kleemola-Kujala E, Räsänen L. Relationship of oral hygiene and sugar consumption to risk of caries in children. Community Dent Oral Epidemiol. 1982 Oct;10(5):224-33. https://doi.org/10.1111/j.1600-0528.1982.tb00384.x

82. Pessan JP, Silva SM, Lauris JR, Sampaio FC, Whitford GM, Buzalaf MA. Fluoride uptake by plaque from water and from dentifrice. J Dent Res. 2008 May;87(5):461-5. https://doi.org/10.1177/154405910808700501

83. Cury JA, Tenuta LM. Evidence-based recommendation on toothpaste use. Braz Oral Res. 2014;28(Spec No):1-7. https://doi.org/10.1590/S1806-83242014.50000001

84. Pessan JP, Alves KMP, Italiani FM, Ramires I, Lauris JR, Whitford GM, et al. Distribution of fluoride and calcium in plaque biofilms after the use of conventional and low-fluoride dentifrices. Int J Paediatr Dent. 2014 Jul;24(4):293-302. https://doi.org/10.1111/ipd.12073

85. Phantumvanit $\mathrm{P}$, Makino Y, Ogawa H, Rugg-Gunn A, Moynihan P, Petersen PE, et al. WHO global consultation on public health intervention against early childhood caries. Community Dent Oral Epidemiol. 2018 Jun;46(3):280-7. https://doi.org/10.1111/cdoe.12362

86. Walsh T, Worthington HV, Glenny AM, Marinho VC, Jeroncic A. Fluoride toothpastes of different concentrations for preventing dental caries. Cochrane Database Syst Rev. 2019;3(3):CD007868. https://doi.org/10.1002/14651858.CD007868.pub3

87. Kumar S, Tadakamadla J, Johnson NW. Effect of toothbrushing frequency on incidence and increment of dental caries: a systematic review and meta-analysis. J Dent Res. 2016 Oct;95(11):1230-6. https://doi.org/10.1177/0022034516655315

88. Carvajal P, Vernal R, Reinero D, Malheiros Z, Stewart B, Pannuti CM et al. Periodontal disease and its impact on general health in Latin America. Section II: Introduction part II. Braz Oral Res. 2020 Apr;34(supl 1):e023. https://doi.org/10.1590/1807-3107bor-2020.vol34.0023

89. Sheiham A, Maizels J, Cushing A, Holmes J. Dental attendance and dental status. Community Dent Oral Epidemiol. 1985 Dec;13(6):304-9. https://doi.org/10.1111/j.1600-0528.1985.tb00461.x

90. National Collaborating Centre for Acute Care (UK). Dental recall: recall interval between routine dental examinations. London: Nationa Collaborating Centre for Acute Care; 2004.

91. Wang NJ, Petersen PE, Sveinsdóttir EG, Arnadóttir IB, Källestål C. Recall intervals and time used for examination and prevention by dentists in child dental care in Denmark, Iceland, Norway and Sweden in 1996 and 2014. Community Dent Health. 2018 Mar;35(1):52-7. https://doi.org/10.1922/CDH_4186Wang06

92. Riley P, Worthington HV, Clarkson JE, Beirne PV. Recall intervals for oral health in primary care patients. Cochrane Database Syst Rev. 2013 Dec;(12):CD004346. https://doi.org/10.1002/14651858.CD004346.pub4

93. Pitts NB, Zero DT, Marsh PD, Ekstrand K, Weintraub JÁ, Ramos-Goez F, et al. Dental caries. Nat Rev Dis Primers. $2017 ; 3: 17030$. https://doi.org/10.1038/nrdp.2017.30

94. Marinho VC, Worthington HV, Walsh T, Clarkson JE. Fluoride varnishes for preventing dental caries in children and adolescents. Cochrane Database Syst Rev. 2013;(7):CD002279. https://doi.org/10.1002/14651858.CD002279.pub2

95. Weyant RJ, Tracy SL, Anselmo TT, et al. Topical fluoride for caries prevention: executive summary of the updated clinical recommendations and supporting systematic review. J Am Dent Assoc. 2013 Nov;144(11):1279-1291. https://doi.org/10.14219/jada.archive.2013.0057

96. Martignon S, Pitts NB, Goffin G, Mazevet M, Douglas GV, Newton JT, et al. CariesCare practice guide: consensus on evidence into practice. Br Dent J. 2019 Sep;227(5):353-62. https://doi.org/10.1038/s41415-019-0678-8

97. Fisberg M, Kovalskys I, Gómez G, et al. Total and added sugar intake: assessment in Eight Latin American countries. Nutrients. 2018 Mar;10(4):389. https://doi.org/10.3390/nul0040389 
98. Oliveira BH, Grisolia BM, Santos AP. Children's toothbrushing practices recommended on the internet by Pediatric Dentistry Associations. Pediatr Dent. 2016 Nov;38(7):484-8.

99. Martignon S, González MC, Tellez M, Guzmán A, Quintero IK, Sáenz V, et al. Schoolchildren's tooth brushing characteristics and oral hygiene habits assessed with video-recorded sessions at school and a questionnaire. Acta Odontol Latinoam. 2012;25(2):163-70.

100. Carvalho TS, Kehrle HM, Sampaio FC. Prevalence and severity of dental fluorosis among students from João Pessoa, PB, Brazil. Braz Oral Res. 2007 Jul-Sep;21(3):198-203. https://doi.org/10.1590/S1806-83242007000300002

101. Hernández-Vásquez A, Azañedo D. [Tooth brushing and fluoride levels in toothpaste used by peruvian children under 12 years old]. Rev Peru Med Exp Salud Publica. 2019 Oct-Dec;36(4):646-52. Spanish. https://doi.org/10.17843/rpmesp.2019.364.4900

102. Feldens CA, Rösing CK, Santos BZ, Cordeiro MM. Pattern of fluoride-containing dentifrice use and associated factors in preschool children from liuí, South Brazil. Oral Health Prev Dent. 2010;8(3):277-85.

103. Martins CC, Oliveira MJ, Pordeus IA, Cury JA, Paiva SM. Association between socioeconomic factors and the choice of dentifrice and fluoride intake by children. Int J Environ Res Public Health. 2011 Nov;8(11):4284-99. https://doi.org/10.3390/ijerph8114284

104. Vettore MV, Moysés SJ, Sardinha LM, Iser BP. [Socioeconomic status, toothbrushing frequency, and health-related behaviors in adolescents: an analysis using the PeNSE database]. Cad Saude Publica. 2012;28 Suppl:s101-13. Portuguese. https://doi.org/10.1590/S0102-311X2012001300011

105. Lopez Del Valle L, Velazquez-Quintana Y, Weinstein P, Domoto P, Leroux B. Early childhood caries and risk factors in rural Puerto Rican children. ASDC J Dent Child. 1998 Mar-Apr;65(2):132-5.

106. Hoffmeister L, Moya P, Vidal C, Benadof D. Factors associated with early childhood caries in Chile. Gac Sanit. 2016 Jan-Feb;30(1):59-62. https://doi.org/10.1016/i.gaceta.2015.09.005

107. Macías C, Díaz D, Caycedo M, Lamus F, Rincón C. [Association of early childhood caries with risk factors in community homes of Instituto Colombiano de bienestar familiar in Zipaquirá, Colombia]. Rev Fac Odontol Univ Antioq. 2016;28(1):123-38. Spanish. https://doi.org/10.17533/udea.rfo.v28nla7

108. Percival T, Edwards J, Barclay S, Sa B, Majumder MAA. Early childhood caries in 3 to 5 year old children in Trinidad and Tobago. Dent J (Basel). 2019;7(1):16. https://doi.org/10.3390/dj7010016

109. Melo MMDC, Souza WV, Goes PSA. Increase in dental caries and change in the socioeconomic profile of families in a child cohort of the primary health care in Northeast Brazil. BMC Oral Health. 2019;19(1):183. https://doi.org/10.1186/s12903-019-0871-9

110. Ramón-Jimenez R, Castañeda-Deroncelé M, Corona-Carpio MH, Estrada-Pereira GA, Quinzán-Luna AM. Risk factors of dental decay in school children aged 5 to 11]. Medisan (Santiago De Cuba). 2016;20(5):604-10. Spanish.

111. Cipriano-Martínez D, Chipana-Herquinio C. [Association between oral hygiene and the prevalence of dental caries in schoolchildren from 6 to 12 years of age at the San Gabriel Educational Institution, in the Villa Maria del Triunfo district of Lima, in 2017] Rev Cient Odontol. 2018;6(2):167-76.

112. García Pérez A, Barrera Ortega CC, González-Aragón Pineda ÁE, Villanueva Gutiérrez T, Pérez Pérez NG, Calderon Uriostegui D. An inverse relationship between obesity and dental caries in Mexican schoolchildren: a cross-sectional study. Public Health. 2020 Mar;180:163-7. https://doi.org/10.1016/i.puhe.2019.10.028

113. Bedos C, Brodeur JM. [Determinants of dental caries in Haitian schoolchildren and implications for public health]. Sante. 2000 May-Jun;10(3):161-8. Spanish.

114. Palacios C, Rivas-Tumanyan S, Morou-Bermúdez E, Colon AM, Torres RY, Elías-Boneta AR. Association between type, amount, and pattern of carbohydrate consumption with dental caries in 12-year-olds in Puerto Rico. Caries Res. 2016;50(6):560-70. https://doi.org/10.1159/000450655

115. Fernández-Vega LR, Barrueco-Botiel LB, Díaz del Mazo L, Rosales-Torres I, Barzaga-Domínguez Y. [Dental decay in adolescents of a Venezuelan community]. Medisan (Santiago De Cuba). 2014;18(8):1043-50. Spanish.

116. Arrieta-Vargas LM, Paredes-Solís S, Flores-Moreno M, Romero-Castro NS, Andersson N. [Prevalence of dental caries and associated risk factors: a cross-sectional study among preparatory (high school) students from Chilpancingo, Guerrero, Mexico]. Rev Odontol Mex. 2019;23(1):31-41. Spanish.

117. Carmo CD, Ribeiro MR, Teixeira JX, Alves CM, Franco MM, França AK, et al. Added sugar consumption and chronic oral disease Burden among adolescents in Brazil. J Dent Res. 2018 May;97(5):508-14. https://doi.org/10.1177/0022034517745326

118. Rivera-Cruz AM, Artigas-Alonso A, Buitrago-Pavón E, Viguera-Prieto Y. [Prevalence and Risk Factors of Dental Caries in Patients of Urbano Noris Municipality] ccm. 2017; 21(1): 139-154. Spanish.

119. Díaz-Sánchez LS, Jiménez-Castellanos MI, Páez-Delgado D, Díaz-Sánchez LH. [Oral diseases and risk factors in the geriatric population of a family doctor's office]. Medisan (Santiago De Cuba). 2018;22(5):483-9. Spanish.

120. World Health Organization. Guideline: sugars intake for adults and children. Geneva: WHO; 2015.

121. Grummon AH, Hall MG. Sugary drink warnings: a meta-analysis of experimental studies. PLoS Med. 2020 May;17(5):e1003120. https://doi.org/10.1371/journal.pmed.1003120 
122. Twetman S. Caries risk assessment in children: how accurate are we? Eur Arch Paediatr Dent. 2016 Feb;17(1):27-32. https://doi.org/10.1007/s40368-015-0195-7

123. Mejàre I, Axelsson S, Dahlén G, Espelid I, Norlund A, Tranæus S, et al. Caries risk assessment: a systematic review. Acta Odontol Scand. 2014 Feb;72(2):81-91. https://doi.org/10.3109/00016357.2013.822548

124. Powell LV. Caries prediction: a review of the literature. Community Dent Oral Epidemiol. 1998 Dec;26(6):361-71. https://doi.org/10.1111/j.1600-0528.1998.tb01974.x

125. Swedish Council on Technology Assessment in Health Care. Caries: diagnosis, risk assessment and non-invasive treatment. a systematic review. Stockholm: Swedish Council on Technology Assessment; 2008. (SBU Yellow Report, n. 188).

126. Twetman S, Fontana M. Patient caries risk assessment. Monogr Oral Sci. 2009;21:91-101. https://doi.org/10.1159/000224214

127. Fontana M, Young DA, Wolff MS. Evidence-based caries, risk assessment, and treatment. Dent Clin North Am. 2009 Jan;53(1):149-61. https://doi.org/10.1016/i.cden.2008.10.003

128. Twetman S, Fontana M, Featherstone JD. Risk assessment: can we achieve consensus? Community Dent Oral Epidemiol. 2013 Feb;41(1):e64-70. https://doi.org/10.1111/cdoe.12026

129. Cagetti MG, Bontà G, Cocco F, Lingstrom P, Strohmenger L, Campus G. Are standardized caries risk assessment models effective in assessing actual caries status and future caries increment? A systematic review. BMC Oral Health. 2018;18(1):123. https://doi.org/10.1186/s12903-018-0585-4

130. Christian B, Armstrong R, Calache H, Carpenter L, Gibbs L, Gussy M. A systematic review to assess the methodological quality of studies on measurement properties for caries risk assessment tools for young children Int J Paediatr Dent. 2018 Nov. https://doi.org/10.1111/ipd.12446

131. Buzalaf MA, Hannas AR, Kato MT. Saliva and dental erosion. J Appl Oral Sci. 2012 Sep-Oct;20(5):493-502. https://doi.org/10.1590/S1678-77572012000500001

132. Buzalaf MA, Ortiz AC, Carvalho TS, Fideles SO, Araújo TT, Moraes SM, et al. Saliva as a diagnostic tool for dental caries, periodontal disease and cancer: is there a need for more biomarkers? Expert Rev Mol Diagn. 2020 May;20(5):543-55. https://doi.org/10.1080/14737159.2020.1743686

133. Pyati SA, Naveen Kumar R, Kumar V, Praveen Kumar NH, Parveen Reddy KM. Salivary flow rate, pH, buffering capacity, total protein, oxidative stress and antioxidant capacity in children with and without dental caries. J Clin Pediatr Dent. 2018;42(6):445-9. https://doi.org/10.17796/1053-4625-42.6.7

134. Medeiros ML, Mendes LL, Lopes SL, Araújo EL, Silva IC, Medeiros EN, et al. Analysis of oral health conditions and risk factors for dental caries in patents with sickle cell disease. RGO Rev Gauch Odontol. 2018;66(3):232-8. https://doi.org/10.1590/1981-863720180003000063408

135. Berman N, Vivino F, Baker J, Dunham J, Pinto A. Risk factors for caries development in primary Siogren syndrome. Oral Surg Oral Med Oral Pathol Oral Radiol. 2019 Aug;128(2):117-22. https://doi.org/10.1016/i.0000.2019.04.011

136. Takahashi N, Nyvad B. The role of bacteria in the caries process: ecological perspectives. J Dent Res. 2011 Mar;90(3):294-303. https://doi.org/10.1177/0022034510379602

137. Carvalho JC. Caries process on occlusal surfaces: evolving evidence and understanding. Caries Res. 2014;48(4):339-46. https://doi.org/10.1159/000356307

138. Carvalho JC, Ekstrand KR, Thylstrup A. Dental plaque and caries on occlusal surfaces of first permanent molars in relation to stage of eruption. J Dent Res. 1989 May;68(5):773-9. https://doi.org/10.1177/00220345890680050401

139. Cortes A, Ekstrand KR, Martignon S. Visual and radiographic merged-ICDAS caries progression pattern in 2-6 years old Colombian children: two-year follow-up [published online ahead of print, 2018 Nov 15]. Int J Paediatr Dent. 2018 Nov; https://doi.org/10.1111/ipd.12448

140. Cortes A, Martignon S, Qvist V, Ekstrand KR. Approximal morphology as predictor of approximal caries in primary molar teeth. Clin Oral Investig. 2018b Mar;22(2):951-9. https://doi.org/10.1007/s00784-017-2174-3

141. Schüler IM, Haberstroh S, Dawczynski K, Lehmann T, Heinrich-Weltzien R. Dental caries and developmental defects of enamel in the primary dentition of preterm infants: case-control observational study. Caries Res. 2018;52(1-2):22-31. https://doi.org/10.1159/000480124

142. Costa FS, Silveira ER, Pinto GS, Nascimento GG, Thomson WM, Demarco FF. Developmental defects of enamel and dental caries in the primary dentition: A systematic review and meta-analysis. J Dent. 2017 May;60:1-7. https://doi.org/10.1016/i.jdent.2017.03.006

143. Vargas-Ferreira F, Salas MM, Nascimento GG, Tarquinio SB, Faggion CM Jr, Peres MA, et al. Association between developmental defects of enamel and dental caries: A systematic review and meta-analysis. J Dent. 2015 Jun;43(6):619-28. https://doi.org/10.1016/j.jdent.2015.03.011

144. Diéguez-Pérez M, Nova-García MJ, Mourelle-Martínez MR, Bartolomé-Villar B. Oral health in children with physical (Cerebral Palsy) and intellectual (Down Syndrome) disabilities: systematic review I. J Clin Exp Dent. 2016 Jul;8(3):e337-43. https://doi.org/10.4317/jced.52922 
145. Usuga-Vacca M, Marin-Zuluaga DJ, Castellanos JE, Martignon S. Association between root/coronal caries and individual factors in institutionalised elderly using ICDAS severity and activity. BMC Oral Health. 2021 Mar;21:146. https://doi.org/10.1186/s12903-021-01520-4

146. Segovia-Villanueva A, Estrella-Rodriguez R, Medina-Solis CE, Maupomé G. Dental caries experience and factors among preschoolers in southeastern México: a brief communication. J Public Health Dent. 2006;66(2):88-91. https://doi.org/10.1111/j.1752-7325.2006.tb02561.x

147. Velásquez N, Pérez-Ybarra L, Urdaneta CJ, Pérez-Domínguez M. Sialometry and concentration of phosphate and calcium in stimulated whole saliva and gingival crevicular fluid and its association with dental caries in schoolchildren. Biomedica. 2019;39(1):157-169. https://doi.org/10.7705/biomedica.v39i1.4069

148. Gambetta-Tessini K, Mariño R, Ghanim A, Calache H, Manton DJ. The impact of MIH/HSPM on the carious lesion severity of schoolchildren from Talca, Chile. Eur Arch Paediatr Dent. 2019 Oct;20(5):417-23. https://doi.org/10.1007/s40368-019-00416-w

149. Taboada-Aranza O, Rodríguez-Nieto K. [Prevalence of plaque and dental decay in the first permanent molar in a school population of south Mexico City]. Bol Méd Hosp Infant México. 2018;75(2):113-8. Spanich. https://doi.org/10.24875/BMHIM.M18000016

150. Villanueva Gutiérrez T, Barrera Ortega CC, García Pérez A, González-Aragón Pineda AE. Relationship between Molar Incisor Hypomineralization (MIH) severity and cavitated carious lesions in schoolchildren. Acta Odontol Latinoam. 2019 Dec;32(3):133-40.

151. Acevedo AM, Ray MV, Socorro M, Rojas-Sánchez F. Frequency and distribution of Mutans Streptococci in dental plaque from caries-free and caries-affected Venezuelan children. Acta Odontol Latinoam. 2009;22(1):15-20.

152. López-Olvera G, Linares Vieyra C, González Guevara MB, Martínez Gómez D, Morales Estrella SL, Flores Hernández, ND, et al. [Risk level and caries incidence in children attended at a predoctoral stomatology clinic]. Rev ADM; 75(5): 261-268, sept.-oct. 2018. Spanish.

153. Cornejo LS, Brunotto M, Hilas E. [Salivary factors associated to the prevalence and increase of dental caries in rural schoolchildren]. Rev Saude Publica. 2008 Feb;42(1):19-25. Spanish. https://doi.org/10.1590/S0034-89102008000100003

154. Rodrigues dos Santos MT, Bianccardi M, Celiberti P, de Oliveira Guaré R. Dental caries in cerebral palsied individuals and their caregivers' quality of life. Child Care Health Dev. 2009 Jul;35(4):475-81. https://doi.org/10.1111/j.1365-2214.2009.00976.x

155. Martínez-Pabón MC, Morales-Uchima SM, Martínez-Delgado CM. [Dental caries in young adults regarding saliva's microbiological and physical-chemical characteristics]. Rev Salud Publica (Bogota). 2013 Nov-Dec;15(6):867-77. Spanish.

156. Jørgensen MR, Twetman S. A systematic review of risk assessment tools for early childhood caries: is there evidence? Eur Arch Paediatr Dent. 2020 Apr;21(2):179-84. https://doi.org/10.1007/s40368-019-00480-2

157. Senneby A, Mejàre I, Sahlin NE, Svensäter G, Rohlin M. Diagnostic accuracy of different caries risk assessment methods: a systematic review. J Dent. 2015 Dec;43(12):1385-93. https://doi.org/10.1016/j.jdent.2015.10.011

158. Fee PA, Riley P, Worthington HV, Clarkson JE, Boyers D, Beirne PV. Recall intervals for oral health in primary care patients. Cochrane Database Syst Rev. 2020;2020(10):CD004346. https://doi.org/10.1002/14651858.CD004346.pub5

159. Tellez M, Gomez J, Pretty I, Ellwood R, Ismail Al. Evidence on existing caries risk assessment systems: are they predictive of future caries? Community Dent Oral Epidemiol. 2013 Feb;41(1):67-78. https://doi.org/10.1111/cdoe.12003

160. Doméjean S, Baneriee A, Featherstone JD. Caries risk/susceptibility assessment: its value in minimum intervention oral healthcare. Br Dent J. 2017 Aug;223(3):191-7. https://doi.org/10.1038/sj.bdj.2017.665

161. Evans RW, Feldens CA, Phantunvanit P. A protocol for early childhood caries diagnosis and risk assessment. Community Dent Oral Epidemiol. 2018 Oct;46(5):518-25. https://doi.org/10.1111/cdoe.12405

162. Ritter AV, Preisser JS, Puranik CP, Chung Y, Bader JD, Shugars DA, et al. A predictive model for root caries incidence. Caries Res. 2016;50(3):271-8. https://doi.org/10.1159/000445445

163. Zhang J, Leung KC, Sardana D, Wong MC, Lo EC. Risk predictors of dental root caries: a systematic review. J Dent. 2019 Oct;89:103166. https://doi.org/10.1016/i.jdent.2019.07.004

164. Gomez J, Ellwood RP, Martignon S, Pretty IA. Dentists' perspectives on caries-related treatment decisions. Community Dent Health. 2014 Jun;31(2):91-8.

165. Pitts N, Melo P, Martignon S, Ekstrand K, Ismail A. Caries risk assessment, diagnosis and synthesis in the context of a European Core Curriculum in Cariology. Eur J Dent Educ. 2011 Nov;15 Suppl 1:23-31. https://doi.org/10.1111/j.1600-0579.2011.00711.x

166. Martignon S, Gomez J, Tellez M, Ruiz JA, Marin LM, Rangel MC. Current cariology education in dental schools in Spanish-speaking Latin American countries. J Dent Educ. 2013 Oct;77(10):1330-7. https://doi.org/10.1002/j.0022-0337.2013.77.10.tb05607.x

167. Martignon S, Marín LM, Pitts N, Jácome-Liévano S. Consensus on domains, formation objectives and contents in cariology for undergraduate dental students in Colombia. Eur J Dent Educ. 2014 Nov;18(4):222-33. https://doi.org/10.1111/eje.12091

168. Abreu-Placeres N, Grau-Grullón P, Naidu R, García-Godoy F, Newton JT, Ekstrand KR, et al. Cariology consensus for undergraduates at dental schools in the Caribbean region. Eur J Dent Educ. 2020 Dec. https://doi.org/10.1111/eje.12651

169. Ferreira-Nóbilo NP, Rosário de Sousa ML, Cury JA. Cariology in curriculum of Brazilian dental schools. Braz Dent J. 2014;25(4):265-70. https://doi.org/10.1590/0103-6440201300149

170. Gouvea DB, Groisman S, Bönecker M, Sampaio F, Paiva S, Kriger L, et al. Cariology education for undergraduate Brazilian dental students. RGO Rev Gaúch Odontol. 2018;66(3):239-44. https://doi.org/10.1590/1981-863720180003000073428 
- Risk factors for dental caries in Latin American and Caribbean countries

171. Díaz-Yokens M, González S, Giacaman RA, Araya-Bustos F, Moncada G, Martignon S. Cariology curriculum in Chilean Universities. Rev Clín Periodoncia Implantol Rehabil Oral. 2018;11(2):98-101. https://doi.org/10.4067/S0719-01072018000200098

172. Aránguiz-Freyhofer V, Marró-Freitte ML, Ramírez-Lobos V, Moncada-Cortes G. Contenidos de cariología impartidos por escuelas dentales chilenas: estudio transversal. Rev Clín Periodoncia Implantol Rehabil Oral. 2019;12(1):31-6. https://doi.org/10.4067/S0719-01072019000100031

173. Gonzalez CD, Okunseri C. Senior dental students' experience with Cariogram in a pediatric dentistry clinic. J Dent Educ. 2010 Feb;74(2):123-9. https://doi.org/10.1002/i.0022-0337.2010.74.2.tb04861.x

174. Goolsby SP, Young DA, Chiang HK, Carrico CK, Jackson LV, Rechmann P. The Effects of Faculty Calibration on Caries Risk Assessment and Quality Assurance. J Dent Educ. 2016 Nov;80(11):1294-300. https://doi.org/10.1002/i.0022-0337.2016.80.11.tb06214.x

175. Young DA, Alvear Fa B, Rogers N, Rechmann P. The Effect of calibration on caries risk assessment performance by students and clinical faculty. J Dent Educ. 2017 Jun;81(6):667-74. https://doi.org/10.21815/JDE.017.013

176. Pozos-Guillén A, Molina G, Soviero V, Arthur RA, Chavarria-Bolaños D, Acevedo AM. Management of dental caries lesions in Latin American and Caribbean countries. Braz Oral Res. 2021;35(suppl 1):e055. https://doi.org/10.1590/1807-3107bor-2021.vol35.0055 
Risk factors for dental caries in Latin American and Caribbean countries. Braz Oral Res. 2021;35:e053. https://doi.org/10.1590/18073107bor-2021.vol35.0053

\author{
p. 2, column 2, last line \\ Were is read: \\ DMFT data collected 12 y previously \\ It should read: \\ Previously collected 12-year DMFT data
}

\author{
p. 4, column 2, line 9 \\ Were is read: \\ dmft values from 5-6 y previously \\ It should read: \\ previously collected 5 to 6-year DMFT values \\ p. $9, \S 2$, line 8 \\ Were is read: \\ for $>2$ months \\ It should read: \\ for $>12$ months
}


Risk factors for dental caries in Latin American and Caribbean countries. Braz Oral Res. 2021;35:e053. https://doi.org/10.1590/18073107bor-2021.vol35.0053

Page 9, §2, lines 8 and 9

Where is read:

and with a high frequency ${ }^{79}$ of daily sugars' intake. ${ }^{79}$

It should read:

and with a high frequency. ${ }^{79}$ 